\title{
BIRD COMMUNITIES AND VEGETATION COMPOSITION IN NATURAL AND SEMI-NATURAL FORESTS OF MEGALOPOLIS: CORRELATIONS AND COMPARISONS OF DIVERSITY INDICES (KYIV CITY, UKRAINE)
}

\author{
OLENA BLINKOVA*, TETYANA SHUPOVA
}

National University of Life and Environmental Sciences of Ukraine, Kyiv, Ukraine; e-mail: elena.blinkova@gmail.com Institute for Evolutionary Ecology NAS of Ukraine, Kyiv, Ukraine

* Author for correspondence

\begin{abstract}
Blinkova O., Shupova T.: Bird communities and vegetation composition in natural and semi-natural forests of megalopolis: correlations and comparisons of diversity indices (Kyiv city, Ukraine). Ekológia (Bratislava), Vol. 37, No. 3, p. 259-288, 2018.
\end{abstract}

\begin{abstract}
Assessment of correlations and comparisons of diversity indices between birds communities and vegetation composition of the forest ecosystem is an important subject of synecological research to identify the intensity of human impact on the flora and fauna in megalopolis. Urban recreation is one of the major causes of violation of the structural and functional integrity of the forest ecosystem. Studies on avian complex and phytocoenosis have focused on the impact of urban recreation on the soil surface, compositions of trees, shrub and herbaceous layers and species, trophic and ecological compositions of nesting-birds and feeding-birds communities. This article compares the measurement of the diversity of bird communities and forestry vegetation (diversity indices, dominance indices, evenness indices) in the natural and semi-natural forests of the Kyiv city on a gradient of recreational transformation. The stands formed consist of Quercus robur L., Carpinus betulus L., Acer platanoides L., Tilia cordata L., Ulmus glabra Huds., Fraxinus excelsior L. and Prunus avium L. The floristic list comprised 65 grass species. A total of 49 species of avifauna were found, including 44 species that were protected by the Bern, Bonn and Washington Conventions. There were significant correlations between vertical and horizontal heterogeneities of tree distribution and abundance, species richness and nesting density of birds. The interrelationship between species diversity of birds and floristic richness was also confirmed.
\end{abstract}

Key words: plant vegetation; avifauna; indices of diversity, dominance, and evenness; recreational transformation.

\section{Introduction}

Forests play a core role in biosphere stability because of the significant area, capacity, duration of development, forest productivity and complexity of structural and functional organisation (Migunova, 1993; Mirkin et al., 2002). The response of a forest ecosystem to changing 
environmental conditions is determined by its biological resources (Ramenskii, 1971; Rabotnov, 1992; Mirkin et al., 2002; Blinkova, 2014; Blinkova, Shupova, 2017; Blinkova, Ivanenko, 2018). Natural and semi-natural forests play an important role of buffer elements in the composition of urbanised landscapes regarding the spread and reduction of the negative impact of anthropogenic factors. Forest ecosystems of megalopolis have a significant anthropogenic transformation.

Urban recreation is one of the main anthropogenic factors that lead to a significant transformation of integrity of natural and semi-natural forests of megalopolis in Ukraine. An assessment of the consequences of the recreational impact on forest ecosystems should be carried with synecological analysis of a relationship between the phyto- and zoo-components. Furthermore, numerous studies in forested areas have emphasised the importance of urbanisation gradient to examine the response of the biotic community. It is well known that mechanical human impact on forest is manifested in trampling of leaf litter, surface soil compaction and mechanical damage to trees and herbaceous cover (Rusin, 2003; Blinkova, 2014; Lavrov et al., 2016, a,b). These violations lead to changes in ecological regimes in the forest ecosystem. This causes structural and functional changes in the fauna, in particular in the species, taxonomic, trophic and ecological composition of the birds' ecological groups (guilds) (Blinkova, Shupova, 2017).

Birds are a particularly advantageous taxonomic group that is visually and acoustically conspicuous and can thus provide an efficient means of evaluating habitat change in forest ecosystems (Sekercioğlu, 2006; Etterson et al., 2007; Fischer et al., 2007; Gardner et al., 2008; Whelan et al., 2008). Increasing urbanisation often results in simplified habitats, a community of birds with fewer species dominated by abundant non-native species and changes in guilds of birds (Marzluff et al., 1998). Variations of characteristics of the forest ecosystem, formed under the influence of urban recreation, have shown the relationships between phytocoenotic parameters and species diversity and density of nesting birds (Conner, Dickson, 1997; Chaplygina et al., 2016; Blinkova, Shupova, 2017). The approaches to relationships between birds communities and forest compositions based on the measurement of phytocoenotic parameters, indices of vertical and horizontal heterogeneities, species diversity and density of breeding birds (MacArthur R., MacArthur J., 1961; Wilson, 1974; O'Connor, 1981; Kurlavichus, 1986; Fuller, Moreton, 1987; Wilson et al., 1994; Catsadorakis, 1997; Walther, 2002). Availability of data about the transformation of the evolutionally formed consortium relation between forest vegetation and birds composition will deepen the knowledge about anthropogenic changes in the state, productivity and development of forest ecosystems (Chaplygina, 2015; Blinkova, Shupova, 2017; Blinkova, Ivanenko, 2018).

The aim of the study was to evaluate correlations and indices of diversity between bird communities and vegetation composition in natural and semi-natural forests in urban conditions depending on the degree of recreational transformation of the environment.

\section{Material and methods}

\section{Study site}

Study sites were all located within the Kyiv city. The natural and semi-natural forests are located inside the city. Kyiv is located on the right and left banks of the Dnipro River at the border between the Forest-Steppe zone and the 
Polissya of Ukraine following the geo-botanical division of Ukraine (Biluk, 1977). The area of the city is $835.6 \mathrm{~km}^{2}$, of which 31,300 ha are natural and semi-natural forests. The average annual temperature for the period 2016-2017 was $8.8^{\circ} \mathrm{C}$. The climate is a semi-continental type for the Forest-Steppe zone. The geomorphological structure of Kyiv belongs to 3 geomorphological zones: South Polissya, Dnipro, Azov-Dnipro Soddy-podzolic soils, gray forest soils and sod meadow soils are the main soil types in Kyiv (Gavriluk, 1956). In the survey conducted between 12 and 25 June 2016, we distinguished 4 localities of forests in Kyiv city. All localities were belonged to the nature reserve fund of Ukraine (Table 1).

T a b l e 1. General characteristics of studied forests.

\begin{tabular}{|l|l|l|l|l|l|l|}
\hline $\begin{array}{l}\text { EP } \\
\text { No. }\end{array}$ & Name of tract & $\begin{array}{l}\text { GPS } \\
\text { coordinates }\end{array}$ & $\begin{array}{l}\text { Year } \\
\text { established }\end{array}$ & $\begin{array}{l}\text { Affiliation to the } \\
\text { nature reserve fund }\end{array}$ & $\begin{array}{l}\text { Area } \\
\text { (ha) }\end{array}$ & Phytogenesis \\
\hline 1 & Teremky & $\begin{array}{l}50^{\circ} 21^{\prime} 40^{\prime \prime} \mathrm{N}, \\
30^{\circ} 27^{\prime} 15^{\prime \prime} \mathrm{E}\end{array}$ & 2007 & $\begin{array}{l}\text { National Natural } \\
\text { Park "Holosiivskyi” }\end{array}$ & 93.8 & Natural vegetation \\
\hline 2 & $\begin{array}{l}\text { Holosiivskyi } \\
\text { lis }\end{array}$ & $\begin{array}{l}50^{\circ} 22^{\prime} 01^{\prime \prime} \mathrm{N}, \\
30^{\circ} 30^{\prime} 30^{\prime \prime} \mathrm{E}\end{array}$ & 2007 & $\begin{array}{l}\text { National Natural } \\
\text { Park “Holosiivskyi” }\end{array}$ & 1879.43 & Natural vegetation \\
\hline 3 & Lysa Hora & $\begin{array}{l}50^{\circ} 23^{\prime} 42^{\prime \prime} \mathrm{N}, \\
30^{\circ} 32^{\prime} 53^{\prime \prime} \mathrm{E}\end{array}$ & 1994 & $\begin{array}{l}\text { Historical and } \\
\text { cultural monument- } \\
\text { museum “Kyivska } \\
\text { fortetsia” }\end{array}$ & 137.1 & $\begin{array}{l}\text { Semi-natural } \\
\text { vegetation }\end{array}$ \\
\hline 4 & Nivki & $\begin{array}{l}50^{\circ} 27^{\prime} 40^{\prime \prime} \mathrm{N}, \\
30^{\circ} 25^{\prime} 13^{\prime \prime} \mathrm{E}\end{array}$ & 1972 & $\begin{array}{l}\text { Monument of land- } \\
\text { scape art of national } \\
\text { importance }\end{array}$ & 44.94 & $\begin{array}{l}\text { Semi-natural } \\
\text { vegetation }\end{array}$ \\
\hline
\end{tabular}

Note: ${ }^{\star}$ The location of experimental plots.

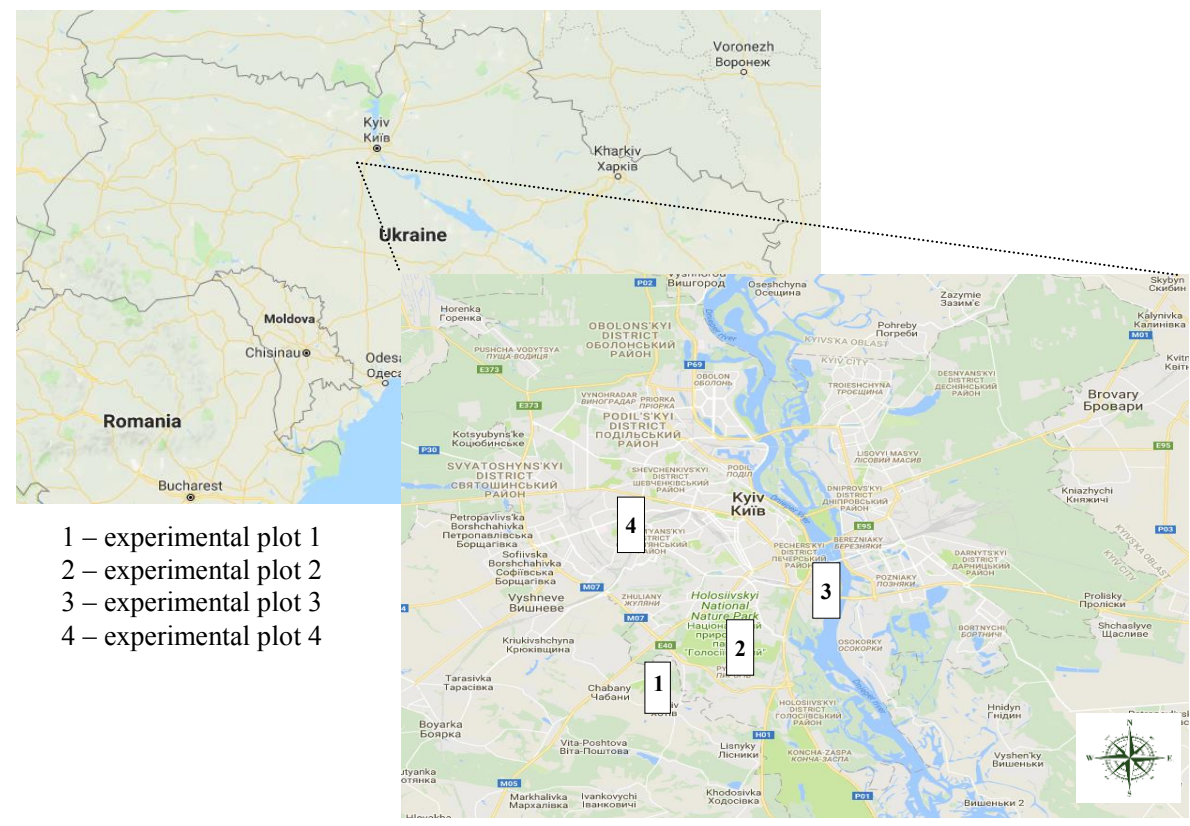

Fig. 1. Geographical distribution of the studied area. The symbols indicate the location and the number of experimental plots. 


\section{Data collection and processing}

The urban forests were selected for the analyses because recreational impact is maximised in these objects. Walking tracks and children's sports grounds are available in all model forests. Each experimental plot was established according to the detailed route-method of study (Dilis, 1974; Vasilevich, 1992; Mirkin et al., 2002). The experimental plots (EPs) that are representative of the forests were chosen by reconnaissance method of study. According to reconnaissance observations of recreational data, the EPs were divided into 4 types, designated as intensive (EP4; 0.75 ha), medium (EP3; $0.74 \mathrm{ha})$, moderate (EP2; $0.76 \mathrm{ha})$ and weak (EP1; $0.70 \mathrm{ha})$ stages of recreational transformation of biotope (Fig. 1).

Birds were nesting during this period. Passeriformes were actively singing or feeding chicks. At the same time, they were clearly visible. Observations of the birds were carried out during morning (7.00-11.00) or evening (18.00-19.30). The weather conditions were favourable for bird surveys. The wind was absent. The air temperature was $25-28^{\circ} \mathrm{C}$. The song activity of Passeriformes was high.

The state of the soil surface layer was determined according to Polyakov and Plugatar (2009). The state of soil surface layer was classified into the following categories: 1 , undisturbed soil; 2 , weakened mulch (single passes); 3 , footpath in mulch; 4 , footpath or road without mulch; 5 , footpath or road with washaways; 6 , deposition and washaways made by recreants descending on steep slopes. The stages of digression of soil surface layer were the following: stage I, under which the $3 \mathrm{rd}, 4 \mathrm{th}, 5$ th and 6 th categories of disturbance cover up to $2 \%$ of the area of experimental plot; stage II, from $2 \%$ to $10 \%$ of area; stage III, $10-25 \%$ of area; stage IV, $26-40 \%$ of area; stage V, more than $40 \%$ of the site area. The stages of the recreational transformation were assessed according to Rusin (2003) (Table 2).

T a ble 2. Recreational transformation of urban forest ecosystem is shown via basic characteristics of the change in state of herbaceous cover, leaf-litter, tree stratum, undergrowth and soil surface. Degradation stages of transformation are shown.

\begin{tabular}{|c|c|c|c|}
\hline $\begin{array}{l}\text { Digression } \\
\text { stage }\end{array}$ & Herbaceous cover and leaf-litter & Tree stratum and undergrowth & Soil surface \\
\hline 1 & $\begin{array}{l}\text { Full species composition of her- } \\
\text { baceous plant, projective cover is } \\
90-100 \% \text {, leaf-litter is not broken }\end{array}$ & $\begin{array}{l}\text { Trees are healthy, undergrowth is numerous } \\
\text { and different ages }\end{array}$ & $\begin{array}{l}\text { Stage I } \\
\text { of digression }\end{array}$ \\
\hline 2 & $\begin{array}{l}\text { Appearance of ruderal, pratal } \\
\text { herbaceous species, projective } \\
\text { cover is } 80-90 \% \text {, leaf-litter begins } \\
\text { to trample down }\end{array}$ & $\begin{array}{l}\text { Trees are weakened, undergrowth is numer- } \\
\text { ous but not different ages }\end{array}$ & $\begin{array}{l}\text { Stage II } \\
\text { of digression }\end{array}$ \\
\hline 3 & $\begin{array}{l}\text { Share of ruderal, pratal herbaceous } \\
\text { species is } 5-10 \% \text {, projective cover } \\
\text { is } 70-80 \% \text {, leaf-litter is trample } \\
\text { down }\end{array}$ & $\begin{array}{l}\text { Trees are weakened or heavily weakened, } \\
\text { undergrowth is limited }\end{array}$ & $\begin{array}{l}\text { Stage III } \\
\text { of digression }\end{array}$ \\
\hline 4 & $\begin{array}{l}\text { Share of ruderal or pratal herba- } \\
\text { ceous species is } 10-20 \% \text {, projective } \\
\text { cover is } 50-70 \% \text {, leaf-litter begins } \\
\text { to deteriorate }\end{array}$ & $\begin{array}{l}\text { Trees are heavily weakened, low viability of } \\
\text { undergrowth is located clumps }\end{array}$ & $\begin{array}{l}\text { Stage IV } \\
\text { of digression }\end{array}$ \\
\hline 5 & $\begin{array}{l}\text { Share of ruderal or pratal her- } \\
\text { baceous species are dominating } \\
\text { species, projective cover is } 0-50 \% \text {, } \\
\text { leaf-litter is completely absent }\end{array}$ & $\begin{array}{l}\text { Trees are heavily weakened or wilting with } \\
\text { significant mechanical damage, under- } \\
\text { growth is absent }\end{array}$ & $\begin{array}{l}\text { Stage } \mathrm{V} \\
\text { of digression }\end{array}$ \\
\hline
\end{tabular}

\section{Herbaceous layer assessment}

Plant composition of all EPs was established according to the botanical detailed route method (Neshataev, 1987; Didukh, 1994; Mirkin et al., 2002). Taxa nomenclature was adopted from Mosyakin and Fedoronchuk (1999), taking into account the existing 'International Code of Nomenclature for algae, fungi, and plants' (Mcneill, 2011). To appraise the diversity of species, the Braun-Blanquet scale (Braun-Blanquet, 1964) was used. The adventive index was calculated as a percentage of the adventitious species encountered at EP (Burda, 2006). 
The health condition of trees (category of state trees) was appraised in accordance with the Sanitary Forest Regulation in Ukraine (2016). The stand state index was calculated as a sum of the values of the tree state index of trees in a certain category divided by the total number of examined trees:

$$
I_{c}=\frac{\sum k_{i} \cdot n_{i}}{N},
$$

where $\mathrm{k}_{\mathrm{i}}$ is the category of tree state $(\mathrm{I}-\mathrm{VI}), \mathrm{n}_{\mathrm{i}}$ is the number of trees in a certain category of tree state and $\mathrm{N}$ is the total number of trees.

The stands with index values ranging from 1 to 1.5 are considered as healthy (I), $1.51-2.50$ as weaker ones (II), 2.51-3.50 as heavily weakened ones (III), 3.51-4.50 as wilting ones (IV), 4.51-5.50 as recently dead (V) and 5.51-6.50 as old dead stands (VI).

In order to avoid the influence of the irregular intensity of silvicultural practice on the index of stand state, for each category of states, the weighted average Kraft classes (WAKC; vitality composition of tree vegetation) were calculated as the sum of the number of trees of each Kraft class multiplied by stand state index (I-V), which was divided by the total number trees in a certain category of state (Eytungen, 1949).

$$
W A K C=\frac{\sum k_{k c} \times I_{\mathbf{c}}}{n_{i}},
$$

where $\mathrm{k}_{\mathrm{kc}}$ is the number of trees in each Kraft class, $\mathrm{I}_{\mathrm{c}}$ is the index of the stand state and $\mathrm{n}_{\mathrm{i}}$ is the number of trees in a certain state category.

For each stand, forest mensuration parameters were estimated: age $(A)$, average weighted diameter $\left(D_{\text {ave }}\right)$, average weighted height $\left(\mathrm{H}_{\text {ave }}\right)$, fluctuations range $\left(\mathrm{D}_{\min }-\mathrm{D}_{\max } ; \mathrm{H}_{\min }-\mathrm{H}_{\max }\right)$, standard deviation (SD), stand density (N) and stand basal area as a sum of tree areas $\left(\mathrm{G}_{\mathrm{n}}\right)$. Morphometric parameters were calculated by an optical altimeter (Suunto PM-5) and callipers (Waldmeister $100 \mathrm{alu).} \mathrm{Mechanically} \mathrm{damaged} \mathrm{woody} \mathrm{plants} \mathrm{were} \mathrm{the} \mathrm{trees} \mathrm{and} \mathrm{bushes}$ that have cut or sawn live branch, injury on the stem reaching cambium or prominent features of such damage independent of time such were inflicted.

\section{Birds surveys}

Bird communities of all EPs was researched according to the transect method (Novikov, 1953; Järvinen, Väisänen, 1975; Bibby et al., 2000). Transect surveys were used to compare the differences in birds between EPs. The length of transect was $0.800-1.000 \mathrm{~m}$. The width on both sides of the direction of movement was $50 \mathrm{~m}$. Nine transects were established on all EPs. Taxa nomenclature of birds was adopted by International Code of the Zoological Nomenclature (1999). The species of birds and the search for their nests in tree canopies visually were determined using binoculars (Barska X-Trail 10x50 Reverse Porro). The audio definition of birds' voices (mp3) was used for the acoustic identification of species.

The density of bird-feeding stations was determined by the number of individuals of each species per $1 \mathrm{~km}$ transect. The SD was calculated for the average density of nesting birds by the number of pair per $1 \mathrm{~km}$ transect. Singing male was counted as a nesting pair for passerine species (Novikov, 1953). The status of the species (breeding, feeding and migration) was determined by the behaviour or presence of a nest for non-Passeriformes species. Community of breeding birds and community of feeding birds were analysed separately.

We also classified bird species into different categories (ecological groups) according to the patterns of microhabitat choice (Muntaner et al., 1983; Snow, Perrins, 1998; Martin, Eadie, 1999; Shirihia et al., 2001; Zavjalov et al., 2005; Camprodon, Brotons, 2006; Bragin E., Bragina T., 2014; Atemasova, 2015). Woody nesters are species of the shrub layer of the undergrowth or tree layer. The individuals of this category are divided into 2 groups: tree canopies nesters and tree hollow nesters. The tree hollow nesters are divided into primary, birds that make hollows (Picidae), and secondary ones, those that settle in ready-made hollows. The category of ground nesters includes birds associated with the forest open habitats. The category of cavity nesters includes birds associated with vertically dissected relief (cracks in rocks, trees, stumps). The category of building nesters includes birds associated with urban construction (in particular, secondary synanthroposized tree hollow nesters or cavity nesters).

We classified bird species into different categories according to the type of feeding: insectivorous birds (these birds feed insects and other invertebrates, Scolopacidae, Motacillidae, Sylviidae, Muscicapidae), granivorous birds (these birds feed grain of plants, Columbidae), birds with mixed type of feeding (e.g. Picidae, Paridae, Fringillidae), predatory birds (these birds hunt and feed on rodents and other small animals, Falconiformes and Strigiformes) and 
pantophagous birds (these birds feed all types of feeding, Corvidae) (Camprodon, Brotons 2006).

The sinantropisation index of nesting birds was determined according to the equation of Jedryczkowski (Klausnitzer, 1990)

$$
W_{s}=\frac{L_{s}}{L_{o}},
$$

where $\mathrm{L}_{\mathrm{s}}$ is the number of synanthropic species and $\mathrm{L}_{\mathrm{o}}$ is a total number of species.

Species of birds forming synanthropic and natural populations were isolated simultaneously into the group of hemysynanthropes (Klausnitzer, 1990). The birds protected by the 'International Conventions for the Protection of Birds' were listed.

\section{Statistical analyses}

For the assessment of plants and birds biodiversity, various methods and indices are available. In this study, the indices of diversity, dominance and equalisation were used for each EP (Magurran, 1998):

1. relative abundance of species or guild

$$
P_{\mathrm{i}}=\frac{N_{i}}{N},
$$

2. the indices of dominance

$$
\begin{aligned}
& d=\frac{N i_{\max }}{N} \text { Berger-Parker } \\
& \lambda=\sum_{i=1}^{S}\left[\frac{N_{i}}{N}\right]^{2} \text { Simpson } \\
& U=\frac{(N-U)}{(N-\sqrt{N})}, U=\sqrt{\sum_{i}^{2}} \text { McIntosh }
\end{aligned}
$$

3. the indices of diversity

$$
\begin{aligned}
& H=-\sum p_{i} \log _{2} \rho_{i} \quad \text { Shannon } \\
& D_{M n}=\frac{S}{\sqrt{N}} \quad \text { Menchinick } \\
& D_{M g}=\frac{(S-1)}{\ln N} \text { Margalef } \\
& D s=\frac{\mathbf{1}}{\lambda} \text { Simpson }
\end{aligned}
$$

4. the indices of evenness

$$
\begin{aligned}
& E=\frac{H^{i}}{\ln S} \text { Pielou } \\
& U s=\sqrt{\sum N_{i}{ }^{2}}, E=\frac{N-U}{N-\frac{N}{\sqrt{S}}} \quad \text { McIntosh }
\end{aligned}
$$

where $\mathrm{N}_{\mathrm{i}}$ is the density of the species in communities, $\mathrm{N}$ is the total number of individuals (for plants, the number of individuals per hectare; for birds, the number of individuals per kilometre), $\mathrm{N}_{\max }$ is the maximum value of $\mathrm{N}_{\mathrm{i}}, \mathrm{U}$ is the McIntosh index of diversity, $p_{\mathrm{i}}$ is the ratio of each species, $S$ is the total number of the species, $\lambda$ is the Simpson index of dominance and $\mathrm{H}^{\prime}$ is Shannon's index of diversity.

Indices of horizontal heterogeneity of vegetation (IHH) and vertical heterogeneity of vegetation (IVH) were calculated in order to describe the vegetation composition in the urban forest ecosystems the feeding and breeding stations of birds (Blondel, Curvillier, 1977; Erdelen, 1984). IVH is Shannon's index for vertical vegetation distribu- 
tions, taking the number of vegetation that touches at each height as individuals in that class. IHH is the coefficient of variation of point-centred quarter distance between the trees (AD).

$$
I H H=\frac{S \cdot D \cdot A D}{A D_{\text {ave }}}
$$

As higher habitat structural heterogeneity often increases, bird species richness because of the presence of more diverse nesting and foraging resources (MacArthur R., MacArthur J., 1961). IHH is the lowest if trees are distributed uniformly but is higher for a random distribution (Sekercioğlu, 2002).

\section{Results}

\section{Assessment of stands morphometric parameters}

The stands at all EP were 2 storeyed. The age composition of stands consisted mainly of trees of the same age (60-80 years). The first storey composed of Quercus robur L. and Carpinus betulus L. The second storey composed of Tilia cordata Mill., Acer platanoides L., Fraxinus ex-

$\mathrm{T}$ a b l e 3. Characteristic of dominant woody vegetation. Variation of forest mensuration parameters for Quercus robur, Acer platanoides, Carpinus betulus, Tilia cordata, Fraxinus excelsior and Ulmus glabra is presented.

\begin{tabular}{|c|c|c|c|c|c|c|c|c|c|}
\hline $\begin{array}{l}\text { EP } \\
\text { No. }\end{array}$ & Species & $\begin{array}{l}\text { Age } \\
\text { (years) }\end{array}$ & $\begin{array}{l}\mathbf{N} \\
\text { (pieces) }\end{array}$ & $\begin{array}{l}D_{\text {ave }} \\
(\mathbf{c m})\end{array}$ & $\mathrm{D}_{\min }-\mathrm{D}_{\max } ; \mathrm{SD}$ & $\begin{array}{l}\mathbf{H}_{\text {ave }} \\
(\mathbf{m})\end{array}$ & $\mathrm{H}_{\min }-\mathrm{H}_{\max } ; \mathrm{SD}$ & $\mathbf{P}$ & $\begin{array}{l}G_{n} \\
\left(\mathbf{m}^{2} h a^{-1}\right)\end{array}$ \\
\hline \multirow[t]{4}{*}{1} & Q. robur & $60-80$ & 172 & 88.1 & $63.2-95.1 ; 8.38$ & 19.0 & $16.1-24.2 ; 2.15$ & \multirow[t]{4}{*}{$0.7-0.8$} & 139.1 \\
\hline & A. platanoides & $40-60$ & 134 & 25.4 & $21.6-45.9 ; 8.99$ & 15.4 & $13.8-18.2 ; 2.01$ & & 81.2 \\
\hline & C. betulus & $60-80$ & 108 & 28.9 & $20.8-34.3 ; 5.18$ & 16.8 & $14.2-18.0 ; 1.75$ & & 66.4 \\
\hline & P. avium & $40-60$ & 51 & 32.7 & $28.7-39.6 ; 4.67$ & 14.8 & $12.6-18.3 ; 2.38$ & & 27.1 \\
\hline \multirow{4}{*}{2} & Q. robur & $60-80$ & 160 & 82.5 & $75.8-120.4 ; 9.21$ & 17.7 & $14.9-19.3 ; 1.99$ & \multirow[t]{4}{*}{$0.6-0.7$} & 199.4 \\
\hline & C. betulus & $60-80$ & 201 & 29.8 & $23.5-40.5 ; 5.98$ & 17.1 & $15.4-19.2 ; 2.14$ & & 99.3 \\
\hline & T. cordata & $60-80$ & 74 & 33.4 & $22.5-38.3 ; 8.01$ & 15.7 & $13.0-16.9 ; 1.60$ & & 54.8 \\
\hline & A. platanoides & $40-60$ & 92 & 26.3 & $21.4-35.5 ; 4.86$ & 13.8 & $12.7-15.4 ; 1.65$ & & 63.1 \\
\hline \multirow[t]{5}{*}{3} & Q. robur & $60-80$ & 122 & 86.1 & $77.1-118.5 ; 8.17$ & 18.0 & $15.3-20.1 ; 1.96$ & \multirow[t]{5}{*}{$0.6-0.7$} & 125.7 \\
\hline & C. betulus & $60-80$ & 64 & 25.6 & $19.5-34.2 ; 5.12$ & 17.3 & $14.3-18.1 ; 1.08$ & & 54.2 \\
\hline & A. platanoides & $40-60$ & 75 & 24.0 & $18.3-30.4 ; 6.79$ & 14.3 & $11.7-17.0 ; 1.96$ & & 70.6 \\
\hline & T. cordata & $60-80$ & 73 & 28.5 & $24.1-36.7 ; 8.74$ & 15.1 & $12.2-17.6 ; 1.99$ & & 63.5 \\
\hline & F. excelsior & $40-60$ & 18 & 20.7 & $16.1-26.4 ; 3.88$ & 14.6 & $13.5-16.8 ; 1.78$ & & 19.1 \\
\hline \multirow[t]{5}{*}{4} & Q. robur & $60-80$ & 98 & 78.5 & $68.4-101.0 ; 9.12$ & 16.9 & $14.7-18.8 ; 1.61$ & \multirow[t]{5}{*}{$0.5-0.6$} & 98.6 \\
\hline & C. betulus & $60-80$ & 78 & 22.4 & $17.0-28.5 ; 6.01$ & 16.1 & $13.7-18.2 ; 1.67$ & & 28.7 \\
\hline & U. glabra & $60-80$ & 79 & 22.3 & $18.8-29.7 ; 7.41$ & 13.9 & $11.8-15.1 ; 1.06$ & & 34.8 \\
\hline & T. cordata & $40-60$ & 65 & 22.8 & $20.4-34.5 ; 9.58$ & 14.0 & $11.5-16.6 ; 1.78$ & & 46.2 \\
\hline & A. platanoides & $40-60$ & 81 & 18.7 & $15.1-27.8 ; 8.54$ & 13.7 & $11.0-17.5 ; 2.47$ & & 57.1 \\
\hline
\end{tabular}

celsior L., Ulmus glabra Huds. and Prunus avium L. The understorey composed of biogroups of Corylus avellana L., Euonymus europaeus L., Euonymus verrucosa Scop., Crataegus oxyacantha L., Frangula alnus Mill., Sorbus aucuparia L., Cerasus avium L. and Rubus fruticous L. 
The analysis of material along the gradient of recreational transformation showed that the highest forest stand parameters (diameter, height, total number of trees and others) were in EP1. The magnitude of stand density was reduced from 0.8 (EP1) to 0.5 (EP4) because of a decrease in the proportion of Quercus robur and Carpinus betulus. The stand basal area was also reduced with the intensification of recreational impact: 199.4-98.6 $\mathrm{m}^{2} \mathrm{ha}^{-1}$ (Quercus robur), 81.2-57.1 $\mathrm{m}^{2}$ ha ${ }^{-1}$ (Acer platanoides), 99.3-28.7 $\mathrm{m}^{2} \mathrm{ha}^{-1}$ (Carpinus betulus), 63.5-46.2 $\mathrm{m}^{2} \mathrm{ha}^{-1}$ (Tilia cordata) (Table 3 ). The number of trees at EPs significantly decreased along the gradient of recreational transformation.

The maximum values of this parameter for Quercus robur, Carpinus betulus, Acer platanoides and Tilia cordata were detected in EP1 that were 5.2-11.0\% higher than others EPs. The weighted average of diameters of all species at the studied EPs was reduced too $(10.9 \%$, Quercus robur; $22.4 \%$, Carpinus betulus; $26.3 \%$, Acer platanoides; $26.7 \%$, Tilia cordata). The growth reduction of trees was observed. The violation of growth in height and diameter of trees was caused by the high intensity of recreational activity. Correlation relationship between height and diameter in EP3 and EP4 was lower compared to EP2 and EP1 $\left(\mathrm{R}_{\mathrm{EP} 4}^{2}=\right.$ $\left.0.69 ; \mathrm{R}_{\mathrm{EP} 3}^{2}=0.77 ; \mathrm{R}_{\mathrm{EP} 2}^{2}=0.89 ; \mathrm{R}_{\mathrm{EP1}}^{2}=0.88\right)$. The regrowth of forest-forming species was better developed at less-transformed EPs. The regrowth of Quercus robur at EP4 was absent. It was deficient at other EPs $(\mathrm{N}=0.24-1.81$ thousand pieces/ha). The regrowth of Acer platanoides was optimal for formed forest conditions $(\mathrm{N}=1.40-4.17$ thousand pieces per ha). The regrowth of Carpinus betulus was composed irregularly $\left(\mathrm{N}_{\mathrm{EP} 4}=0.9\right.$ thousand pieces per ha; $\mathrm{N}_{\mathrm{EP} 3}=1.3 ; \mathrm{N}_{\mathrm{EP} 2}=1.5 ; \mathrm{N}_{\mathrm{EP} 1}=1.2$ thousand pieces per ha).

In general, the average number of regrowth of forest-forming species gradually decreased with an increasing stage of recreational digression (Table 4). The increasing of distance between the trees from $254.6 \mathrm{~cm}$ to $345.5 \mathrm{~cm}$ was recorded at EPs. The value of the index of IVH varied depending on the stage of transformation too. The value of IVH was the lowest (1.93) in EP4 and the highest (2.97) in EP1 (Table 4). The value of IHH was $0.66,0.79,0.80$ and 0.78 in EP1-EP4, respectively.

\section{Tree health and vitality composition}

The analysis of health conditions revealed a weak-stage degree of recreational transformation of biotope in EP1 and an intensive high-stage degree of recreational transformation of biotope in EP4 (Fig. 2). The proportion of healthy trees was $15.1 \%$ at EP4. The proportion of weakened trees was $24.2 \%$, heavily weakened $44.8 \%$ (twice as much) and wilting $0.5 \%$. The

$\mathrm{T}$ a b l e 4. Additional parameters of forest vegetation in different experimental plots. Average distance between trees, average density undergrowth, index of horizontal heterogeneity of vegetation (IHH) and index of vertical heterogeneity of vegetation (IVH) are shown.

\begin{tabular}{|l|c|c|c|c|}
\hline Parameters & EP 1 & EP 2 & EP 3 & EP 4 \\
\hline Average distance between trees (AD) $(\mathrm{cm})$ & $254.0 \pm 5.1$ & $275.7 \pm 13.8$ & $306.0 \pm 15.3$ & $345.5 \pm 17.2$ \\
\hline Average density regrowth (thousand pieces/ha) & $6.87 \pm 0.34$ & $5.45 \pm 0.27$ & $3.54 \pm 0.17$ & $2.30 \pm 0.11$ \\
\hline IHH & 0.78 & 0.80 & 0.79 & 0.66 \\
\hline IVH & 2.97 & 2.44 & 2.15 & 1.93 \\
\hline
\end{tabular}




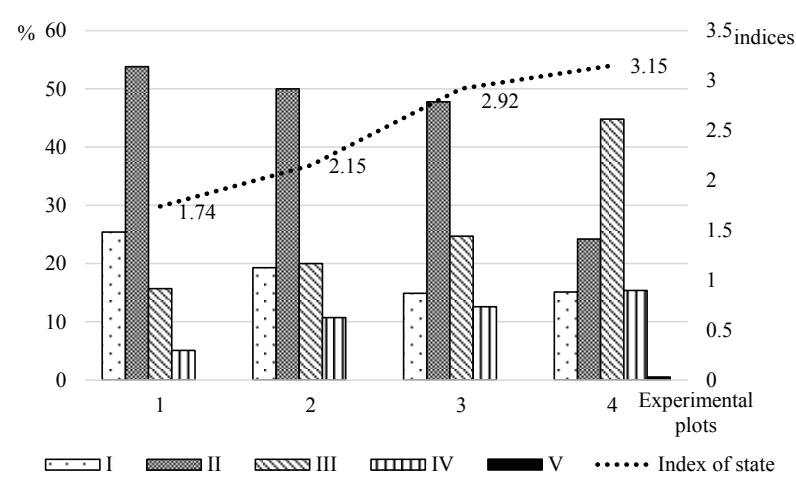

Fig. 2. Health conditions of forest stand in the experimental plots.

T a b l e 5. Vitality of tree composition in different experimental plots. The weighted average of Kraft class (WAKC) is shown.

\begin{tabular}{|c|c|c|c|c|c|}
\hline \multirow{2}{*}{$\begin{array}{c}\text { EP } \\
\text { No. }\end{array}$} & \multicolumn{5}{|c|}{ Categories of tree state } \\
\cline { 2 - 6 } & I & II & III & IV & V \\
\cline { 2 - 6 } & WAKC & WAKC & WAKC & WAKC & WAKC \\
\hline 1 & 1.8 & 2.1 & 4.0 & 4.2 & - \\
\hline 2 & 1.9 & 2.2 & 3.8 & 4.0 & - \\
\hline 3 & 1.5 & 2.4 & 2.6 & 3.1 & - \\
\hline 4 & 2.1 & 2.1 & 2.0 & 3.6 & 4.8 \\
\hline
\end{tabular}

proportion of healthy trees was increased from $14.9 \%$ (EP2) to $25.4 \%$ (EP1) with reduced impact on biotopes. The proportion of weakened trees was increased too (24.2-53.8\%). Instead, the proportion of wilting trees gradually decreased from $44.8 \%$ to $15.7 \%$. Recently dead stands were present only in EP4 (0.5\%). The index of stand state was 1.74 (EP1), 2.15 (EP2), 2.92 (EP3) and 3.15 (EP4).

The analysis of the vitality of stands revealed a similar trend regarding the distribution of categories of tree state. The number of trees of the highest Kraft classes dominated at EP1 with a weak-stage degree of recreational transformation of biotope. WAKC of wilting (WAKC $=4.2)$ and heavily weakened (WAKC = 4.0) in EP1 differed from the data of other EPs (Table 5).

The value of WAKC revealed the absence of pathological processes in EP1. Drying of trees was natural process because of the biological characteristics of species in this EP. WAKC of weakened (WAKC $=2.2$ ) and heavily weakened (WAKC $=3.8$ ) were in EP2. WAKC of weakened $($ WAKC $=2.4)$ and heavily weakened (WAKC $=2.6$ ) were in EP3. Trees of II and III classes Kraft began to wither in EP2. The trees of the lowest Kraft classes dominated at EP4 with an intensive-stage degree of recreational transformation of biotope. WAKC of healthy (WAKC=2.1), weakened (WAKC=2.1) and heavily weakened (WAKC=2.0) were in EP4.

The analysis of vitality composition as an integral index of the population state of Quercus robur, Carpinus betulus, Acer. platanoides and Tilia cordata indicated significant transformation of these species in intensive and medium recreational transformation EP4EP3 compared with moderate and weak recreational transformation EP2-EP1.

\section{Herbaceous and soil surface layers}

The floristic list of the all EPs comprised 65 grass species belonging to 59 genera, 19 families. It included species of Liliopsida and Magnoliopsida. The prevailing families of herbal plants were Asteraceae (18 species, 27.5\%) and Poaceae (10 species, 15.3\%). Species of 
Asteraceae and Poaceae dominated in the disturbed habitats. These were followed by Lamiaceae (5 species, 7.5\%) and Rosaceae (4 species, 6.2\%). Fabaceae and Ranunculaceae had the same distribution of species (3 species, 4.5\%). Brassicaceae, Polygonaceae and Scorphulariaceae were represented by 2 species (3.0\%). Sixteen families were represented by 1 species $(1.5 \%)$.

The most florist saturation (49 species) was detected at the EP1. The projected cover was $83.5 \%$ and was dominated by Asperula odorata L., Galium aparine L., Geranium sylvaticum L., Polygonatum odoratum (Mill.) Druce and Pulmonaria obscura L. Ruderal and adventitious herbaceous species (Chelidonium majus L., Malva sylvestris L., Plantago major L., Stenactis annua L., Urtica dioica L.) were distributed sporadically. The total indicator of the state soil surface was stage II of digression. The total projected cover of herbaceous storey at the EP2 was 75.5\% (33 species). A total of 9.0\% species were ruderal or adventitious (Dactylis glomerata, P. major, Senecio vulgaris L.). Forest species were dominated (Dryopteris filix-mas L., Carex sylvatica L., Geranium sanguineum L., Polygonatum multiflorum). The soil surface was in stage III of degradation. The total projected cover of herbaceous storey at the EP3 was lower than that at the EP2 (65.5\%; 29 species). The herbaceous storey was represented by ruderal and forest species (Stellaria nemorum L., Asperula odorata L., Brachypodium sylvaticum L., Lamium galeobdolon subsp., Poa nemoralis L., P. odoratum and Stellaria holostea L.). The soil surface was in stage III of degradation too. The herbaceous cover of EP4 is rather poor; the total projected cover was 55.5\%. Altogether 21 species were found at EP4. Ruderal and pratal species were dominated at EP4. The indicator species composed of only biogroups of Asarum europaeum L. and Galium aparine (0.5\%). The soil surface was in stage IV of degradation.

The adventive index was $45.5 \%$ (EP4), 29.5\% (EP3), 18.1\% (EP2) and 10.5\% (EP1) at the ecoprofile. In accordance with the results, the stages of recreational transformation of EP were as follows: stage IV in EP4, stage III in EP3, stage II in EP2 and stage I in EP1.

\section{Analysis of bird communities}

Species composition of nesting birds

A total of 49 bird species belonging to 6 orders (Falconiformes, Columbiformes, Cuculiformes, Caprimulgiformes, Piciformes and Passeriformes) were observed during the study at the ecoprofile (Appendix 1). Parus major, Fringilla coelebs and Turdus merula dominated by their number in all communities of birds at EPs. These species are the most typical species in the forest biotopes of the region. This list was complemented by Sitta europaea (EP1), Erithacus rubecula (EP3), Sturnus vulgaris and Turdus pilaris (EP4). A total of 44 bird species (89.8\%) were protected by the 'International Conventions for the Protection of Birds'. About 2 bird species (4.1\%) were regionally rare species. Average density of nesting birds was $2.7 \pm 0.60$ pairs $/ \mathrm{km}$. The highest number of species was detected at the EP2 (36 species, average density $-2.6 \pm 0.60$ pairs $/ \mathrm{km}$ ). The number of nesting species was approximately the same in EP1 (36 species) and EP4 (33 species). The number of nesting species was the least in EP3 (28 species). The species from 4 orders were nesting in EPs. 
In general, avifauna of all the EPs was distributed to the ecological groups: 38 species $(76.6 \%)$ were woody nesters, 16 species $(32.17 \%)$ were tree hollow nesters, 5 species $(10.2 \%)$ were ground nesters and 4 species $(8.2 \%)$ were building nesters. The relationship between birds communities at nesting stations and the digression stage of the forest ecosystem was absent in the medium (EP2) and moderate (EP3) stages of recreational transformation of biotope (Fig. 3).

The ratio of tree hollow nesters and tree canopies nesters were the same in all EPs. The ratio of ground nesters did not have a correlation relationship with the stage of recreational transformation but significantly reduced (to 9.1\%) precisely in the most recreationally transformed EP4. In addition, $12.1 \%$ of birds was observed to use the territory of EP4 for nesting in buildings and structures. These species did not nest in EP4-EP3 with intensive and moderate levels of transformation biotope, although technical constructions were available. Only 1 species (Passer montanus) that used urban buildings and structures for nests was noted in EP4. It was a common species in the communities of birds. The average density of P. montanus was $3.6 \pm 0.81$ pairs $/ \mathrm{km}$. The birds that nest in urban buildings were present in EP1 and EP4 and absent in EP2 and EP3, because of the proximity of residential areas supplying migrants left without nesting stations (hollows) to the limit of their forest habitats. Sinantropisation of communities of nesting birds increased depending on the stage of recreational transformation of natural and semi-natural forests. The number of synanthropic species, their abundance in communities and the sinantropisation index of communities were gradually increased. On the contrary, the increase in appropriate data was significant in EP4 (Fig. 4).

The nesting obligatory synanthropes (Columba livia and Phoenicurus ochruros) were observed in the most transformed EP4. P. ochruros is an alien species of even land of Ukraine. The hemysynanthropic species, which have natural populations, were nested only in others EP. Share of species of birds those forming synanthropic populations was increased in the recreational transformation gradient in communities of feeding birds. The ratio of species increased by 1.5 times and was $45.7 \%$ (EP1), 50.0\% (EP2), 50.0\% (EP3) and 66.7\% (EP4).

Woodpeckers are suppliers of breeding stacks to secondary tree hollow nesters, so it is necessary to consider their place in forest ecosystem. The species composition of the breeding woodpeckers decreased twice from the weak-transformed EP1 to the intensive-transformed EP4.

The abundance of nesting species of woodpeckers was minimal in EP2 and EP3. The density of woodpeckers increased in EP4, because Dendrocopos major nested in this EP with a density of 5.0 par $\mathrm{km}$. This species is actively sinantrophised species and inhabited even small parks of urban residential areas. Most of the species of secondary tree hollow nesters was recorded in the EPs with high density of woodpeckers. The density of secondary tree hollow nesters was fluctuated in the EPs (Fig. 5).

The presence of artificial nests of birds and vents of anthropogenic origin in the fences were influenced by the quantitative indices of secondary hollow-nesting birds. In particular, the mass nesting of Ficedula albicollis in artificial nests of birds was recorded in EP2. Nesting of Parus major in vents of anthropogenic origin is a standard type of nesting. Ficedula 


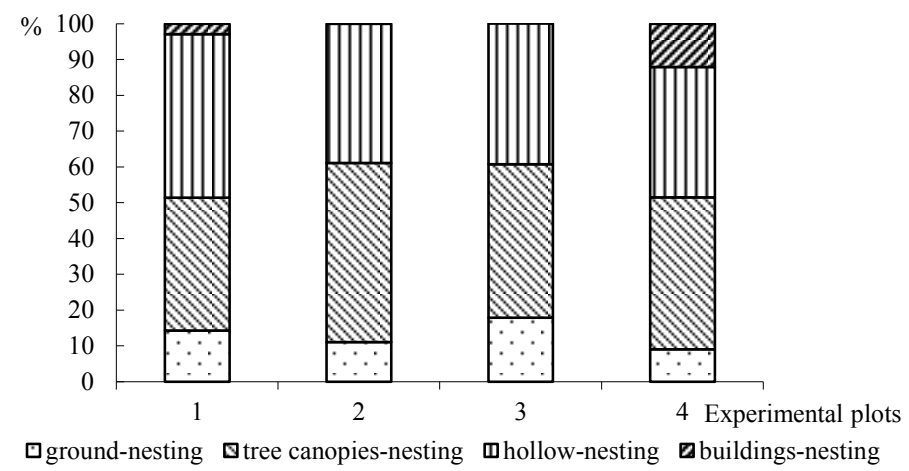

Fig. 3. Distribution of birds in communities by nesting stations.

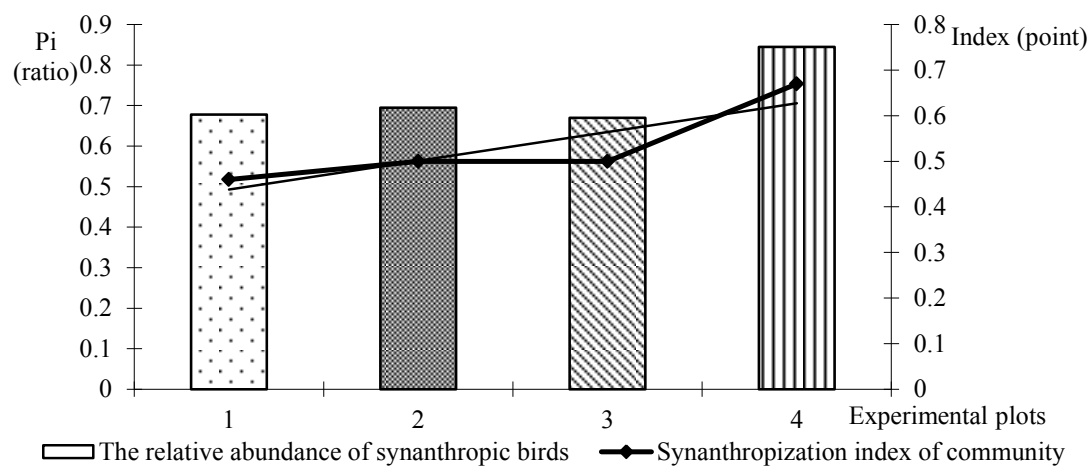

Fig. 4. Sinantropisation of communities of nesting birds.

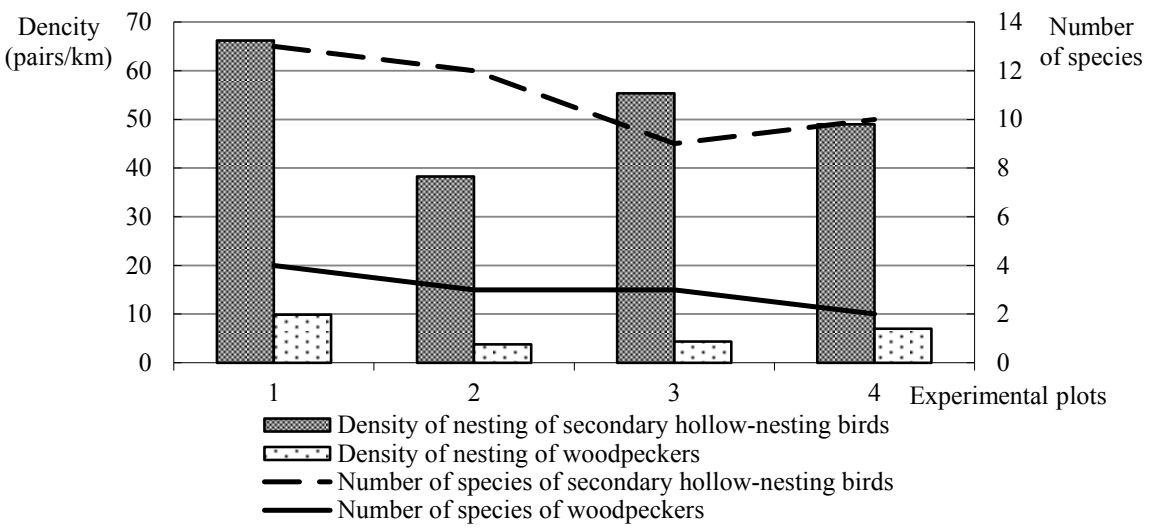

Fig. 5. The ratio of woodpeckers and secondary hollow-nesting birds in birds communities. 
parva and Parus palustris are demanding species, which nest only in a slightly transformed EP (Appendix 1).

\section{Trophic composition}

Nesting birds of natural and semi-natural forests of Kiev were divided into 7 types of feeding (Fig. 6). The birds with mixed type of feeding (24 species, $47.1 \%$ ) were dominated at the ecoprofile. About 18 species (31.4\%) were birds that feed on invertebrates on the surface of ground. The predatory birds in the EPs were represented only by 1 species - the kestrel (Falco tinnunculus). Two species were insectivorous birds that catch insects in air: nightjar

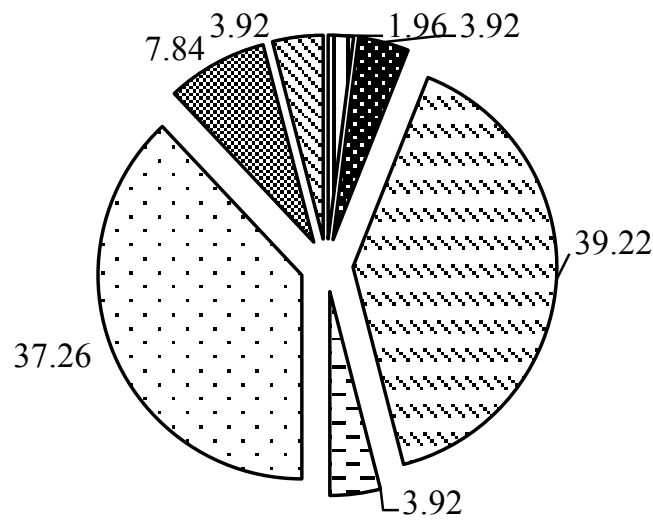

品redators

Q invertebrates and vertebrates

$\square$ invertebrates on the surface

口insectivorous in flight

$\square$ mixed (invertebrates, berries, grains)

圆polyphages

Qgranivorous

Fig. 6. The generalised distribution of avifauna of forest ecosystems of Kiev by types of feeding (in \%).

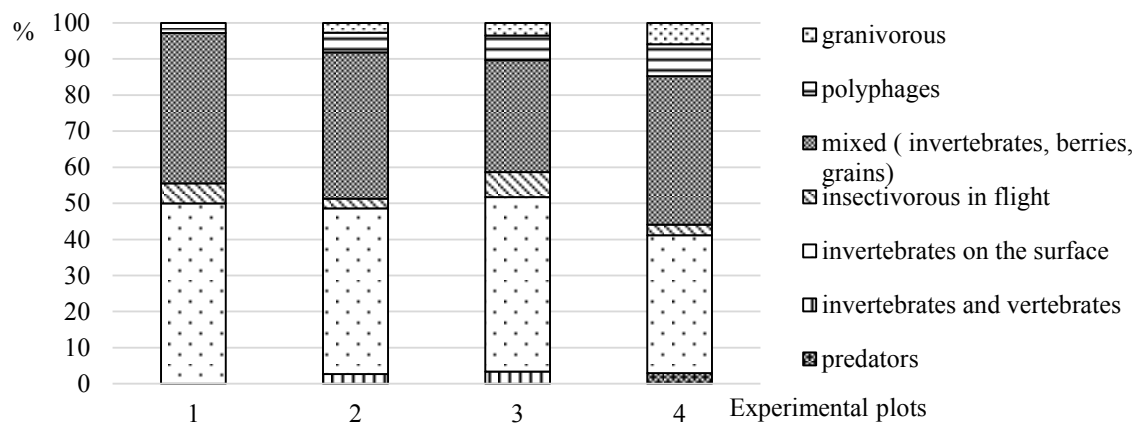

Fig. 7. Distribution of avifauna by types of feeding in experimental plots. 
(Caprimulgus europaeus) and swift (Apus apus). Caprimulgus europaeus nested in EP1 and EP3. Apus apus did not nest in EP1 and EP3 but arrived from neighbouring residential areas only for feeding. Two granivorous species, woodpigeon (Columba palumbus) and rock dove (C. livia), were founded at ecoprofile. The trophic group of birds that feed on invertebrates and vertebrates (Lanius) were also represented by two species: Lanius collurio and L. minor. Polyphages were noted in small numbers: jay (Garrulus glandarius), magpie (Pica pica), hooded crow (Corvus cornix) and raven (C. corax).

The increase in the proportion of granivorous birds and birds with mixed type of feeding, including polyphages, was observed by the gradient of recreational transformation of the forest ecosystem (Fig. 7). Fluctuations in the ratio of other groups have not shown the tendency of dependence. The presence of predatory birds in the intensive-transformed EP4 was due to the fact that Falco tinnunculus is synanthropic species.

\section{Assessment of plants and birds biodiversity}

The assessment of plants and birds biodiversity indicated qualitatively anthropogenic changes in ecological conditions in urban natural and semi-natural forests. The violation of the species composition, density and species richness of communities of plants and birds were observed in EP2 and EP3 compared to the data from EP1 and EP4 (Figs. 8, 9). Indices of birds communities of EP2 differed significantly from the general trend at the ecoprofile. The most species richness and the number of nesting species with the lowest general and average breeding density were noted in EP2. Appropriate indices of plant communities were changed slowly, without sharp fluctuations. The highest average density of plant communities was recorded in the intensive recreational transformed EP4.

\section{Diversity indices}

The indices of diversity of phytocoenoses have shown anthropogenic changes in the ecological conditions of the forest ecosystem of Kyiv. The highest values of Shannon, Menchinick and Margalef indices were in EP1 (Fig. 10). The computed Shannon, Menchinick and Margalef indices for EP2 and EP3 were almost the same. The lowest values of these indices were in EP4, where adventitious and ruderal species had the highest share of phytocoenoses, stage IV of recreational transformation of biotope. Ecological conditions of EP4 were favourable only for dominate adventitious and ruderal species. Other species were in a depressed state. It should be noted that the synchronisation of the indices was violated precisely in EP4. The value of the Simpson indices did not have correlation dependence on the stage of recreational transformation.

No indices of diversity of avifauna had correlation dependence on the stage of recreational transformation and unity of fluctuation. Almost all indices indicated an increase in species richness in EP2 compared to EP1. Shannon and Simpson indices showed a slight decrease in the diversity with a further increase in the recreational transformation of EPs. Menchinick and Margalef indices showed a decrease in diversity in EP3 and increase in diversity in EP4.

Comparative evaluation of indices of diversity of phytocoenoses and avifauna in natural and semi-natural forests on recreational transformation gradient showed that human activi- 
ties equally lead to the violation of composition of plants and birds communities. However, the absence of tendencies in the values of the indices of diversity for the ornithocomponent of forest ecosystem was explained by the fact that the evolution of each communities of birds passed independently of each other. The second reason was related to the mobility of birds and their need for visiting neighbouring habitats and, accordingly, the exchange of individuals between them. The third reason for the absence of synchronisation of changes in the spe-

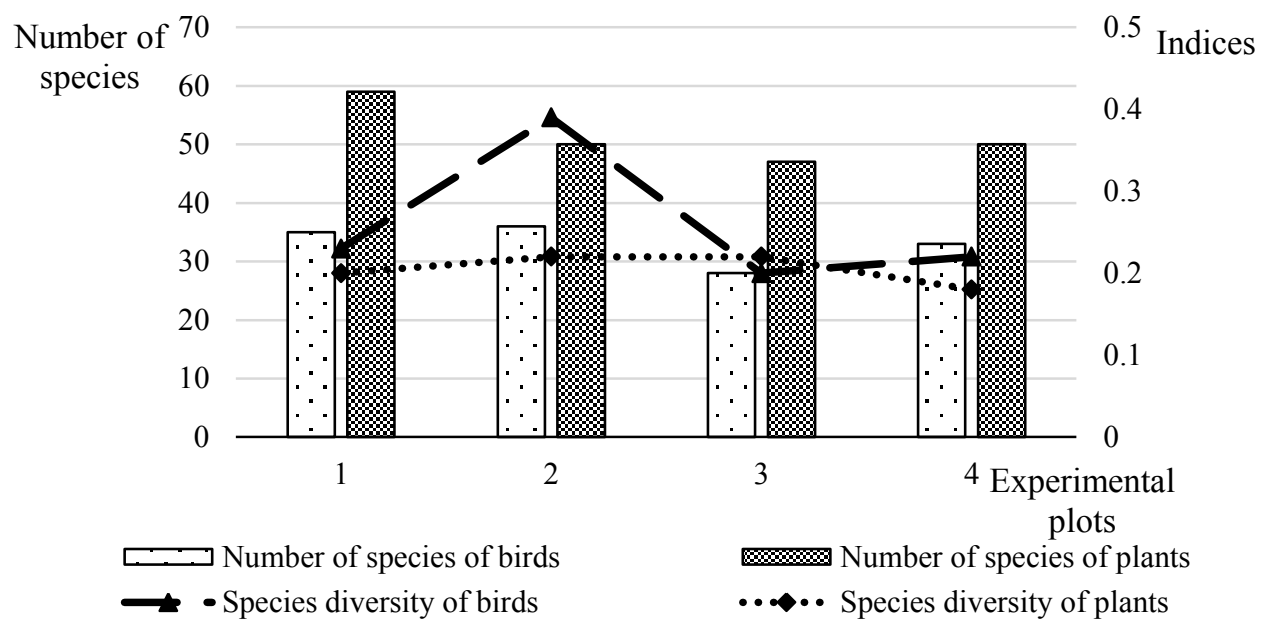

Fig. 8. Species richness of birds and plants communities.

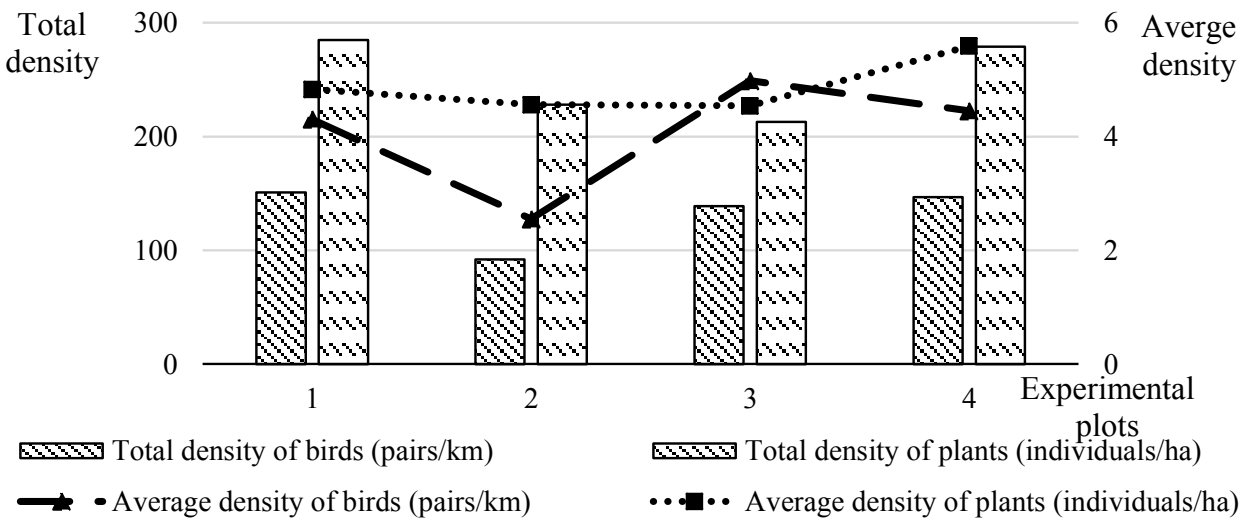

Fig. 9. Density of birds and plants communities. 
cies diversity of birds in different communities, in our opinion, was that the adaptation of bird groups to anthropogenic transformations, in contrast to the adaptation of plants, passed through the serai communities. Consequently, it can be concluded that the response of the birds communities to changes in the plants communities requires additional time.

\section{Dominance indices}

The assessment of dominance indices showed that the level of dominance for plants and birds communities was almost the same for all the EPs (Fig. 11). The highest values of the Simp-

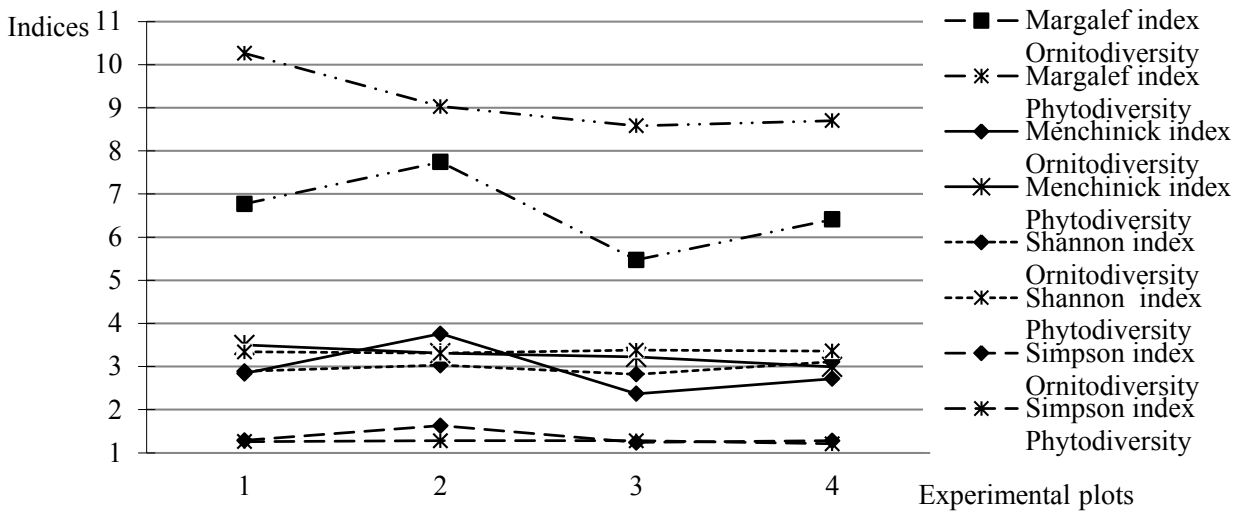

Fig. 10. The comparison of the trends of species diversity indices of plants and birds communities in the experimental plots.

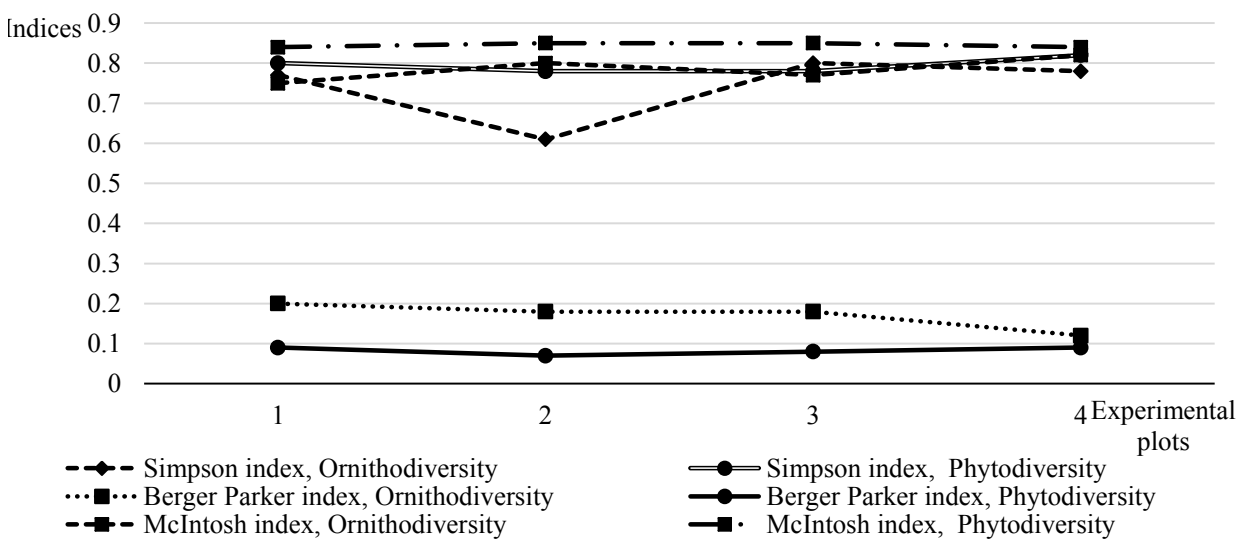

Fig. 11. The comparison of the trends of species dominance indices of plants and birds communities in the experimental plots. 
son index (0.82) for plant communities were recorded in intensive-transformed EP4. This indicated that the ecological conditions were favourable for some species of plants (Dactylis glomerata, Galinsoga parviflora Cav., Sanguisorba annua (L.) Cass, Taraxacum officinale F.H. Wigg and others) in the intensive recreational transformation territory (EP4). Forest species of plants were more depressed. The values of the McIntosh dominance index were the maximum in EP2 and EP3. The values of the Berger-Parker index were minimal in these EPs.

The indices of dominance for bird communities did not show the unity of fluctuations. Only the Berger-Parker index had the most stable values of dominance. It gradually decreased from EP1 to EP4. The Berger-Parker index showed a slight decrease in the pressure of dominant species, especially in the intensive-transformed EP4. This trend was also confirmed by graphs of the curves of the ranking of the relative number of birds species in the communities (Fig. 11). The Simpson index showed a significant decrease in the pressure of dominant species in EP2 with a gradual increase. The McIntosh index gave us the opposite picture: a slight increase in the pressure of dominant species in EP2 and EP4, with a decreasing pressure in EP3.

In general, the assessment of dominance indices for plants and birds communities has showed that the curves of the dominance plant community's indexes had less differences than that of dominance bird community's indexes and also were not synchronised with the recreational transformation gradient.

\section{Evenness indices}

Evenness indices of vegetation layer and ornithocommunity demonstrated a slight increase in the values on the gradient of recreational transformation of the EPs (Fig. 12). Ranked curves of the species composition of birds showed similarities in data results of all the EPs. Evenness indices of ornithocommunity demonstrated balanced equitability of birds in EP4

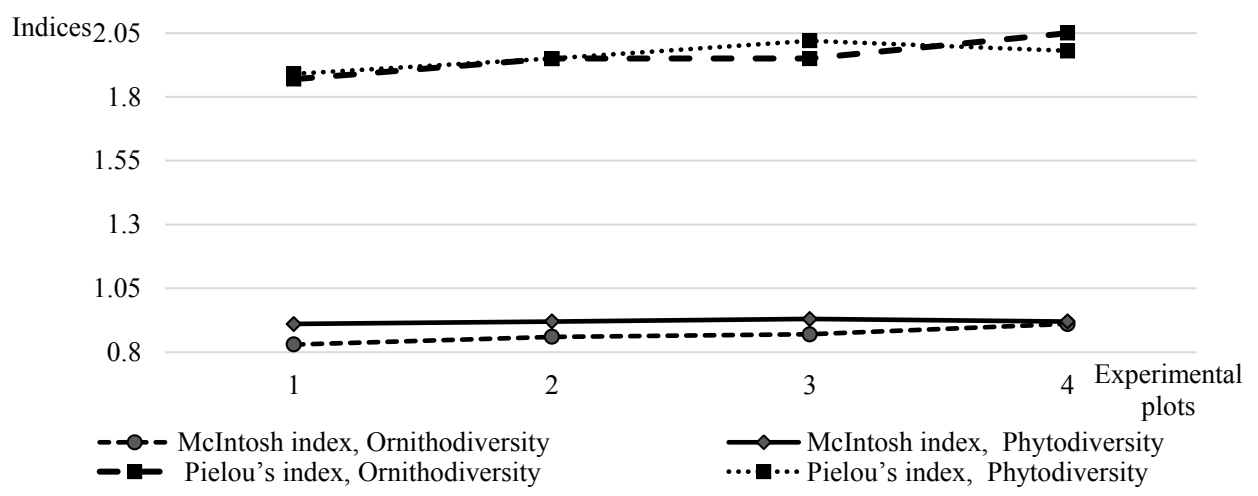

Fig. 12. The comparison of the trends of species evenness indices of plants and birds communities in the experimental plots. 
(Fig. 13b). Significant difference was recorded for dominant species. In particular, the significant difference in the number of dominant species and subdominant common species was detected in EP4 compared to others EPs. The result of the ranked curves analysis confirmed the trend shown by the Berger-Parker index on the pressure of the dominant species (Fig. $13 b)$.

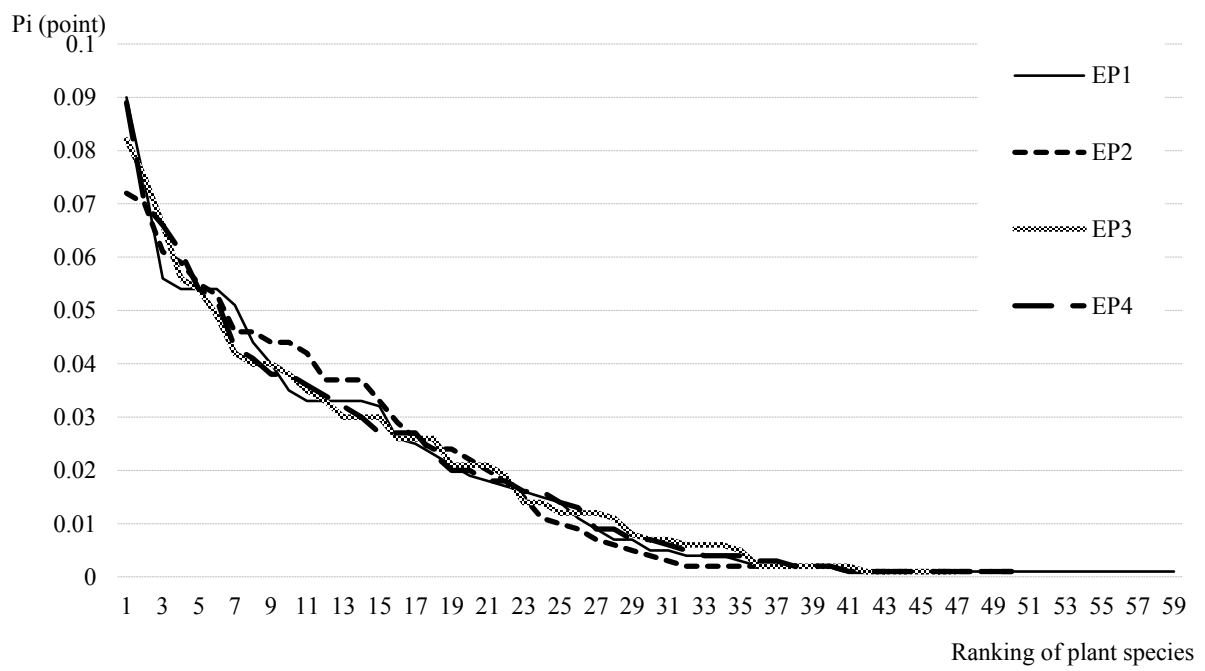

(a)

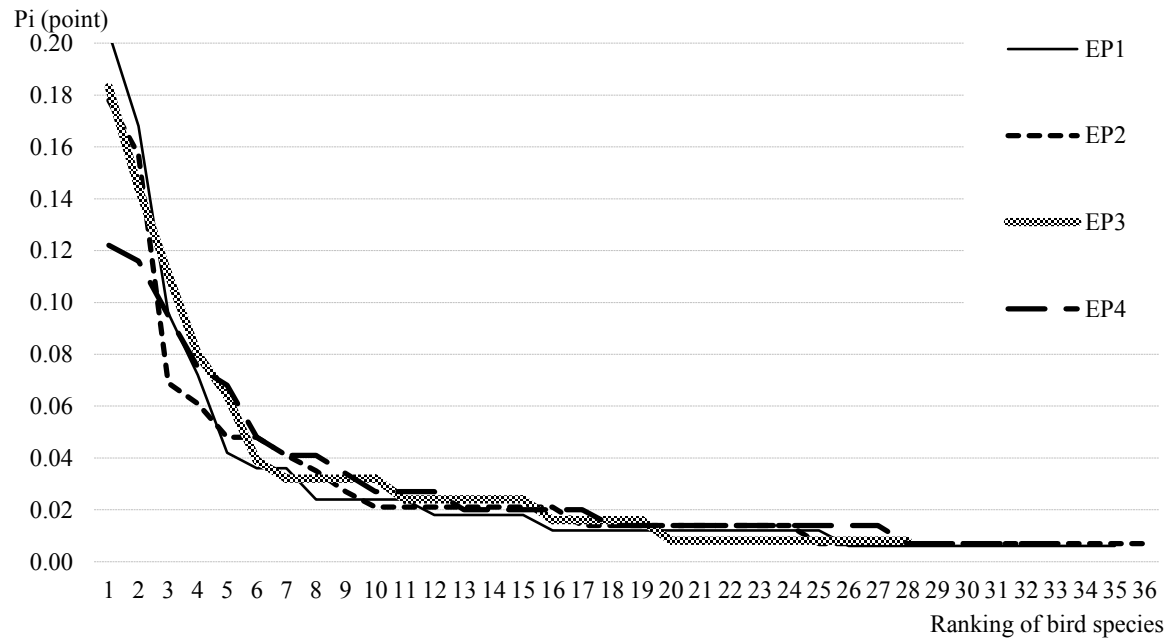

(b)

Fig. 13. Evenness of species in (a) plant communities and (b) feeding birds in the experimental plots. 
This analysis was due to the fact that the formation of birds communities has been completed in EP4, because biotopes have been transformed for a long time and the birds have already adapted to anthropogenic impact. The formation of birds communities has begun recently and the birds have not yet been adapted to the impact in less-transformed natural and semi-natural forests of Kyiv. Such communities were less balanced and more responsive to human interference.

The evenness of species of phytocommunity was balanced. The similarity of the evenness of relative number of plants species was noted for all the EPs (Fig. 13a). Ranked curves showed the best state of dominance of plant communities in EP1 and EP2, where the highest number of species were detected. Thus, the analysis of biodiversity indices showed a discrepancy between the reaction of plants communities and birds communities of natural and semi-natural forests to the recreational transformation by most of the indices.

The Berger-Parker index has demonstrated the similarity in the fluctuations of dominance in the communities, and the Shannon and Simpson indices demonstrated the similarity in the diversity. However, the values of the Shannon and Simpson indices did not depend on the gradient of recreational transformation of forests.

\section{Assessment of other indicators of communities}

Most of the tree canopies nesters was recorded in EP4, where the lowest developed classes of trees (III-V) and the highest state index were found (Fig. 14). Most of the ground nesters was registered in EP1, where the highest developed classes of trees (I-II) and the lowest state index were found. The insignificant decrease in the relative ratio (abundance) of tree hollow nesters was recorded in the investigated EPs. An increase in the ratio of bird's tree canopies nesters depending on the gradient of transformation was also established. The highest abun-

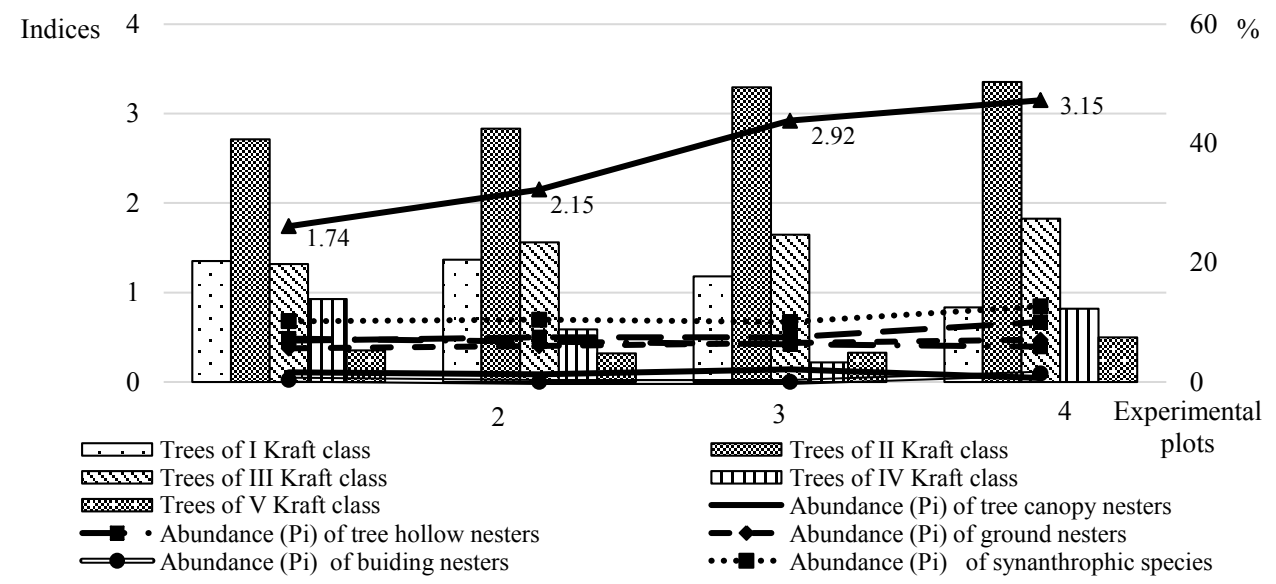

Fig. 14. The share of various ecological groups of birds and vitality and health compositions of trees. 
dance of synanthropic species (0.845) was in EP4. The ratio of other ecological groups of birds by nesting stations was fluctuated, but the interrelation with the gradient of recreational transformation was not established.

It should be noted separately that the increase in the relative number of ground nesters was recorded in the moderate-transformed EP3. This was due to the fact that visitors were raced cyclocross and motocross, reconstructed historical events and collected medicinal herbs in EP3. Consequently, only a fraction of the territory of EP3 was essentially transformed. Another fraction of the territory of EP3 had a lot of microstations suitable for the comfortable existence of birds.

\section{Discussion}

Human activity leads to the disappearance of most species of birds, which are typical for the indigenous forests of the Forest-Steppe, the intensive expansion of birds of meadow and shrubby phytocoenoses (Blinkova, Shupova, 2017). The impact of forestry activity on avifauna depends on the intensity of extraction of timber (Gabbe et al., 2002; Rodewald, Abrams, 2002; Šalek et al., 2010; Pereira et al., 2014; Bergner et al., 2015). The change of mixed forests in forest monoculture leads to a decrease in the species richness of birds, density of the ornithocommunity and its biomass by one-third, indicating a reduction in the volume of ecological niches (Fischer et al., 2007; Gardner et al., 2008; Whelan et al., 2008; Felton et al., 2016). Human factors such as firewood and fodder collection, timber extraction and grazing bring about subtle changes in the habitats available to birds. The authors succeeded in identifying explainable relationships between bird components and habitat types. Different guilds showed preferences for diverse habitats, suggesting that they are directly related to habitat conditions. Moreover, significant relationships between bird species diversity and richness and tree species diversity and richness added more convincing relationships with the overall biodiversity (Chettri et al., 2005).

Conventional management involves the removal of a substantial part of the understory in order to prevent establishment and spread of wildfires. These practices might have negative consequences for birds that depend on shrubs for breeding and foraging, which showed that it was possible to keep breeding species in managed forests as long as sufficient shrub layer was retained in the understory (Camprodon, Brotons, 2006; Heyman, 2010). The analysis of the ecological structure of the birds communities showed that forests are more abundant in species associated with closed forest habitats than other plant associations (Domokos E., Domokos J., 2016). Recent studies suggest that birds communities are influenced by woodland vegetation cover at both the patch and the landscape scales and that these relationships are consistent over time (Ikin et al., 2014).

The analytical results showed that the changes in the species number and density of bird as well as the formation of birds communities follow the changes in forest type and the total foliage. Both the number of bird species and their density decreased with the decrease in total foliage. The similarity in bird community was very low at the breeding time. In the same classification of cluster, no similarity was higher than 0.65 , which indicated that the composition of species had a great difference between all the birds communities. The bird's breeding den- 
sity was closely related to forest growth stage. From the bare grassland ecosystem to climax ecosystem, the density of bird species showed a gradually increasing trend (Wen et al., 2002).

The degradation of natural habitats is a significant factor affecting the fauna in inhabited localities (Tomiałojc, 2007; Grimm et al., 2008; Møller et al., 2015). The authors prove that the mosaic of landscapes increases the species richness of birds. A highly fragmented habitat leads to a decrease in the populations of limited species that have large nesting station and increase the risk of disappearing of these populations (Tews et al., 2004; Sekercioğlu, 2006; Giltena et al., 2007; Moreno-Rueda, Pizzaro, 2009; Šalek et al., 2011; Robles et al., 2012; Domokos E., Domokos J., 2016).

In this study, the natural and semi-natural forests remaining on the territory of the Kyiv are far from each other. The exchange of individuals between communities of birds is limited. These common species are typical for the region: Columba palumbus, Jynx torquilla, Anthus trivialis, Lanius collurio, L. minor, Garrulus glandarius, Pica pica, Sylvia borin, Parus caeruleus, P. montanus, Chloris chloris and Carduelis carduelis. Such fragmentation of the forest landscape leads to separated co-evolutionary process of birds communities and the absence of general communities of birds in all forests of the city. Ecological conditions are different for each EPs; therefore, nesting and feeding stations are suitable only to isolated species of communities. Columba livia, Apus apus, Passer domesticus and P. montanus are dominant nesting species, and Sturnus vulgaris, Corvus cornix, Phoenicurus ochruros, Parus major, P. caeruleus, Chloris chloris and Carduelis carduelis are common species of residential district of Kyiv (Shupova, 2014). The exchange of individuals between communities of these bird species is possible in the forests and residential districts of the city.

The authors indicate that streetscape vegetation plays an important role in influencing urban bird communities, with streetscapes dominated by native plants supporting communities with high native species richness and abundance, whilst exotic and newly developed streetscapes support more introduced bird species and fewer native bird species. Research has also revealed that urban remnants are likely to support more native bird species. Vegetation structure and quality do not appear to be as important a driver as remnant size in determining the richness of native birds communities (White et al., 2009). An analysis of the ecological and species compositions has shown that with insufficient number of nesting woodpeckers in communities, tree hollow nesters will be limited by the number of suitable nesting stations (Angelstam, Mikusinski, 1994; Carlson et al., 1998; Mikusinski et al., 2001; Virkkala, 2006; Woodley et al., 2006; Robles et al., 2011, 2012).

Our research showed that the total density of woodpeckers and their species composition were important. Nesting of only 2 species (Dendrocopos major and D. medius) with a high density had led to a significant increase in the density of Sturnus vulgaris in the communities of the most of the transformed forests. Nesting of D. major and D. medius also caused a change in the species composition and density of nesting birds of the genera Ficedula and Parus.

The authors point out that the communities of nesting birds gradually changes according to the transformation of habitats (Rodewald, Abrams, 2002). Trampling down leads to the transformation of the herbaceous cover, the destruction of shrubbery and the reduction in the proportion of birds ground nesters (Camprodon, Brotons, 2006; Heyman, 2010; Šalek 
et al., 2010). The authors showed that the dogs walking prevents the arrangement of nests and contributes to the reduction in the number of birds associated with the ground level (Shupova, 2017).

In our study, this conclusion is confirmed by the fact that the abundance of ground nesters was less in the forests located in the surroundings of residential districts of the city. The abundance of ground nesters was the highest in the forestland remote from residential districts by transport infrastructure, although biotope had moderate stage of recreational transformation.

The species richness of the birds communities varies according to the transformation of the habitats (Graham et al., 2014). The studies show disturbance of the species composition of birds depending on the recreational transformation of the biotope. Increasing the structural complexity of the forest ecosystem expands the range of nesting and feeding stations of birds (James, Wamer, 1982; Hinsley et al., 1995; Katsimanis et al., 2006).

Our data showed that most of the species richness and the number of nesting species were in the forest with medium stage of anthropogenic transformation. Species composition and the richness of avifauna is due to nesting species that are absent in the intensive-transformed forest (Cuculus canorus, Anthus trivialis, Lanius minor, Hippolais icterina, Aegithalos caudatus) and the presence of species from other biotopes (Jynx torquilla and Emberiza citrinella). The impact of pressure on birds communities is confirmed by the increase in the ratio of woody nesters. This indicates the redistribution of nesting stations in favour of the inaccessible place for a people. Birds have not been adapted to recreational impact, and compositions of ornithocommunities were less balanced in the weak-transformed forest.

The authors attribute this to the limited ability of birds to quickly adapt to dynamic conditions of existence and the development of gradual adaptation (Martin, Joron, 2003; Gill, 2006; Brockerhoff et al., 2008; Graham et al., 2014). The presence of synanthropic species in the birds communities makes it possible to detect the impact of urbanisation on the communities of natural and semi-natural forests (Chaplygina et al., 2016).

Our data also confirm the results of other authors. The nesting obligatory synanthropes (Columba livia and Phoenicurus ochruros) are observed in the most-transformed forest. $P$. ochruros is an alien species of even land of Ukraine. Nesting hemysynanthropes with natural populations were recorded in forest of weak stage of recreational transformation. Given that the components of the bird community used the elements of this landscape differently, the conservation of each element requires the application of different management strategies (Elisa, Schondube, 2015).

Notable differences also occurred with respect to the relative abundance of specific feeding guilds. The natural stands supported higher abundances of invertebrate feeders, omnivores and herbivores, whereas the mature production stands supported more granivores. These outcomes are likely to have arisen because of the increased diversity of forest environments encountered in the natural stands. More diverse forest environments provide increased foraging environments and microhabitats and thus increased opportunities for a wider range of bird species possessing distinctive feeding niches. These differences between the stand types surveyed, as well as their respective landscape setting, also have the capacity to affect the populations of avian predators (Felton et al., 2016). This dependence is also confirmed 


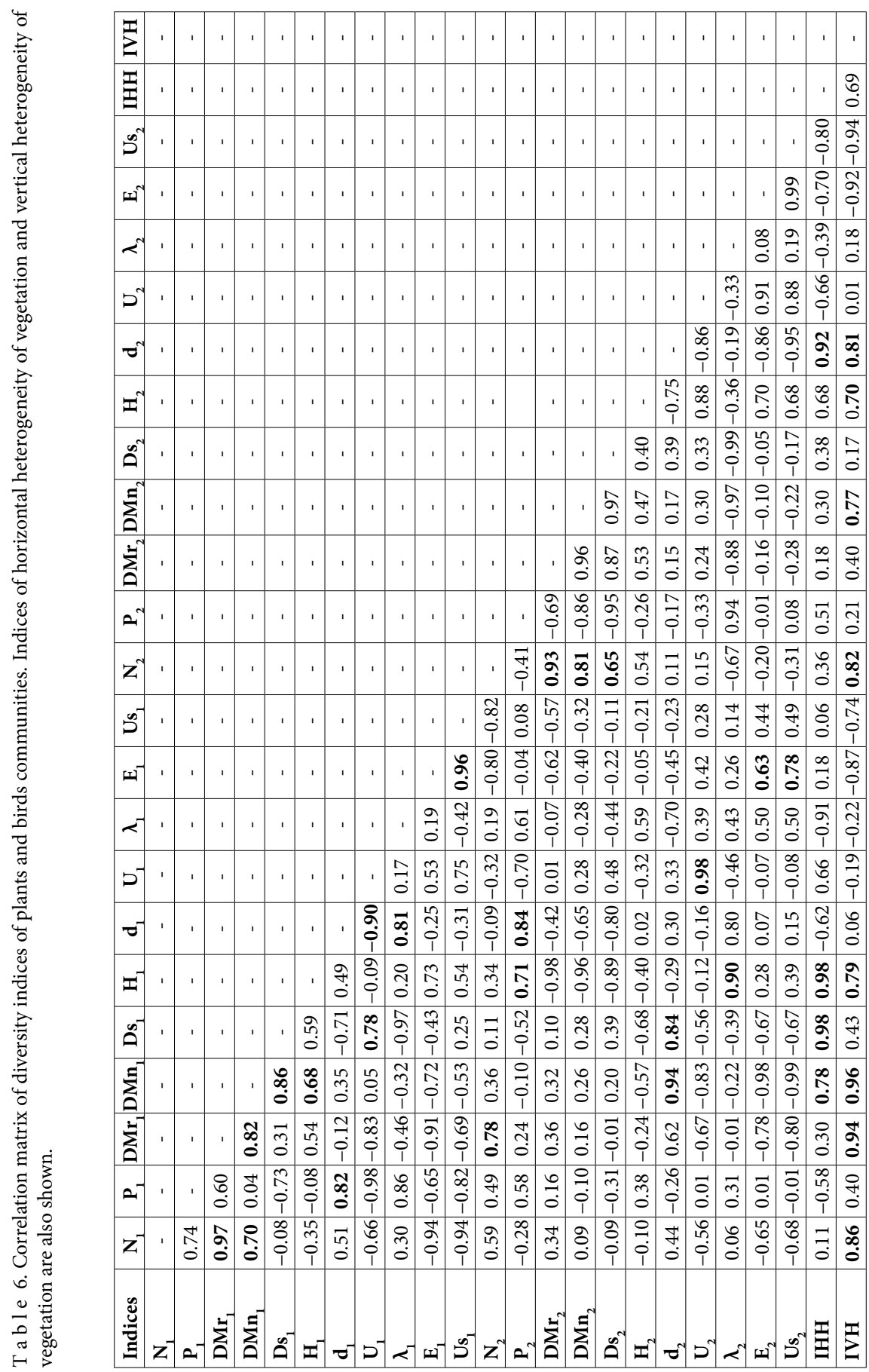


in our study: only 1 species of predators has been observed - synanthropic species, Falco tinnunculus. Pereira et al. (2014) showed that insectivorous warblers were more abundant in dense oak stands with a more extensive cover of understory vegetation (0.9-1.0). Insectivorous, ground-nesting passerines apart from being constrained by lack of suitable nest sites might also face a lack of food resources, which limits its distribution in stands. The relative abundance of birds that feed on stands increases with the cover of understory vegetation (less than 0.9). Birds from agro-forest open habitats increased in abundance in cleared and thinned oak forests, remaining less frequent in denser forests. However, if ligneous vegetation is dense enough, clearing of the vegetation may have negligible effects on birds. If the undergrowth clearing is accompanied by selective thinning, the combined effects of these 2 factors on the bird community appear more intense. This management practice diminishes the abundance of undergrowth bird species and also the thinning induces changes in the composition of the tree-canopy birds and benefits other species associated with agro-forest open habitats (Shirihai et al., 2001).

In our studies, the density of nesting birds of the Piciformes and Passeriformes that feed on the tree stands varied with the gradient of transformation as follows: $56.2-26.5-38.8-28.0$ pairs $/ \mathrm{km}$. The stand density reduced from 0.5 to 0.8 , and the average number of growth too was reduced from 6.87 to 2.3. The distance between the trees increased. Many species of woodpeckers specialise in the use of forest resources and depend on trees to find food and nesting (Mikusinski et al., 2001; Robles et al., 2007; Ciudad et al., 2009; Robles et al., 2012; Touihri et al., 2014). In particular, Dendrocopos medius is an indicator of broad-leaved forests (Robles et al., 2007; Roberge, Angelstam, 2006). In our research, the woodpeckers marked almost everywhere in the natural and semi-natural forests of the megalopolis. Quantitative indices of secondary tree hollow nesters are not closely related to the number of woodpeckers of urban ecosystems in comparison with natural forests through forestry work, which includes artificial nesting for birds (Blinkova, Shupova, 2017).

The assessment of correlations between parameters of plant communities and birds communities confirmed significant relationship between the index of vertical heterogeneity and the number of bird species $(\mathrm{r}=0.82 ; \mathrm{p}<0.01)$. However, significant relationship between the index of vertical heterogeneity and nesting density was not confirmed in our results $(r=0.21)$ (Table 6). A relationship between IVH and the Menchinick index of diversity $(\mathrm{r}=0.74 ; \mathrm{p}<$ $0.01)$ was also noted $(\mathrm{r}=0.77 ; \mathrm{p}<0.01)$. A relationship between IVH and the Shannon index of diversity $(\mathrm{r}=0.70 ; \mathrm{p}<0.01)$ was slightly weaker. It should be noted that the correlation between IVH and Berger-Parker dominance index $(r=0.81 ; \mathrm{p}<0.01)$ was recorded for the first time in this study. This relationship was not confirmed in other articles. The obtained data showed a relationship between the multi-storeyed vertical composition of the forest and the diversity of birds.

The correlation between index of horizontal heterogeneity and Berger-Parker dominance index $(\mathrm{r}=0.81 ; \mathrm{p}<0.01)$ was confirmed in forests of megalopolis. The relationship between density of nesting and IHH was not confirmed, but it was slightly closer $(r=0.51)$ compared to IVH. Thus, our studies confirmed the relationship between the distribution of birds and the IHH of the forest. A relationship between the Menchinick index of plant diversity and the number of species of birds $(r=0.78 ; \mathrm{p}<0.01)$ was observed. Close relationships between 
Shannon index of diversity for plant communities and the total density of birds $(r=0.71$; $\mathrm{p}<0.01)$ and Simpson dominance index for plant communities and the total density of birds $(\mathrm{r}=0.84 ; \mathrm{p}<0.01)$ were also established. The Simpson dominance index for birds communities revealed a relationship with the floristic indices diversity by Menchinick $(\mathrm{r}=0.94 ; \mathrm{p}$ $<0.005)$ and the Simpson $(\mathrm{r}=0.84 ; \mathrm{p}<0.01)$. The presence of a correlation between the bird's species diversity and the floristic richness is evidenced by the obtained data. In other studies, no vegetation variable explained bird's species richness or diversity. Total foliage volume and foliage height diversity were significantly correlated with bird's species diversity in the no forest sites but not in the forested areas. However, foliage height diversity significantly explained the variation in bird's density and species richness in the forest sites (Chamberlain et al., 2007). The results of studies found strong relationships between vegetation associations and landscape position. These patterns were related to disturbance and stress from natural and human processes. Avian populations were strongly related to the vegetation patterns of deciduous cover, but there was not as strong a correspondence with landscape position and the levels of disturbance and stress (Milne, 2003).

\section{Acknowledgement}

This work was supported by the National University of Life and Environmental Sciences of Ukraine, Grant No. 0117 U002647.

\section{References}

Angelstam, P. \& Mikusinski G. (1994). Woodpecker assemblages in natural and managed boreal and hemiboreal forest - a review. Ann. Zool. Fenn., 31(1), 157-172. http://www.sekj.org/AnnZool.html

Atemasova, T. (2015). A structure of bird communities at forests park zone of Kharkov (Ukraine). Belgorod State University Scientific Bulletin, Natural Sciences, 30(3), 74-81.

Bergner, A., Avci, M., Eryiğit, H., Jansson, N., Niklasson, M., Westerberg, L. \& Milberg P. (2015). Influences of forest type and habitat structure on bird assemblages of oak (Quercus spp.) and pine (Pinus spp.) stands in southwestern Turkey. For. Ecol. Manag., 336, 137-147. DOI: 10.1016/j.foreco.2014.10.025.

Bibby, C.J., Burgess, N.D., Hill, D.A. \& Mustoe S.H. (2000). Bird census techniques. London: Academic Press.

Biluk, G. (1977). Geobotanical zoning of Ukraine. Kyiv: Naukova Dumka.

Blinkova, O.I. (2014). Synphytoindication recreational ecological changes conditions of plant formation in protected areas the Borzhava, Zakarpatska lowland. Odesa National University Herald Biology, 19(2), 21-33.

Blinkova, O. \& Shupova T. (2017). Bird communities and vegetation composition in the urban forest ecosystem: correlations and comparisons of diversity indices. Ekológia (Bratislava), 36(4), 366-387. DOI: 10.1515/eko2017-0029.

Blinkova, O. \& Ivanenko O. (2018). Communities of woody vegetation and wood destroying fungi in natural and semi-natural forests of Kyiv city, Ukraine. Central European Forestry Journal, 64, 55-66. DOI: 10.1515/forj2017-0030.

Blondel, J. \& Cuvillier R. (1977). Unemethode simple etrapide pour decrier les habitats doiseaux: le stratiscope. Oikos, 29, 326-331. DOI: 10.2307/3543622.

Bragin, E. \& Bragina T. (2014). Modern composition and structure of the avifauna Naurzum reserve. Journal of Omsk University, 2, 98-101.

Braun-Blanquet J. (1964). Pflanzensoziologie, grundzuge der vegetationskunde. New York: Springer.

Brockerhoff, E.G., Jactel, H., Parrotta, J.A., Quine, Ch.P. \& Sayer J. (2008). Plantation forests and biodiversity: oxymoron or opportunity? Biodivers. Conserv., 17(5), 925-951. DOI: 10.1007/s10531-008-9380-x.

Burda, R.I. (2006). Trends change of phytodiversity in agricultural landscapes of Ukraine. Scientific Bulletin of National Agricultural University of Ukraine, 93, 1-15. 
Camprodon, J. \& Brotons L. (2006). Effects of undergrowth clearing on the bird communities of the Northwestern Mediterranean Coppice Holm oak forests. For. Ecol. Manag., 221(1-3), 72-82. DOI: 10.1016/j. foreco.2005.10.044.

Carlson, A., Sandstrom, U. \& Olsson K. (1998). Availability and use of natural tree holes by cavity nesting birds in a Swedish deciduous forest. Ardea, 86(1), 109-119.

Catsadorakis, G. (1997). Breeding birds from reed beds to alpine meadows. Hydrobiologia, 351, 143-155. DOI: 10.1023/A:1003080911744.

Chamberlain, D.E., Gough, S., Vaughan, H., Vickery, J.A. \& Appleton G.F. (2007). Determinants of bird species richness in public green spaces. Bird Study, 54(1), 87-97. DOI: 10.1080/00063650709461460.

Chaplygina, A.B. (2015). Ecofaunistic analysis and breeding successful of dendrophilous birds on the transformed territories of North-Eastern Ukraine. Studia Biologica, 9(2), 133-146.

Chaplygina, A., Shupova, T. \& Nadtochiy A. (2016). The avifauna of the National Nature Park "Homilshanski Lisy. Biosystems Diversity, 24(1), 124-133. DOI: 10.15421/011615

Chettri, N., Debes, Chandra Deb., Sharma, E. \& Jackson R. (2005). The relationship between bird communities and habitat a study along a trekking corridor in the Sikkim Himalaya. Mt. Res. Dev., 25(3), 235-224. DOI: 10.1659/0276-4741(2005)025[0235:TRBBCA]2.0.CO;2.

Ciudad, C., Robles, H. \& Matthysen E. (2009). Post feeding habitat selection of juvenile middle spotted woodpeckers: a multi-scale approach. Ecography, 32(4), 676-682. DOI: 10.1111/j.1600-0587.2009.05806.x.

Conner, R.N. \& Dickson J.D. (1997). Relationships between bird communities and forest age, structure, species composition and fragmentation in the west gulf coastal plain. Tex. J. Sci., 49, 123-138.

Didukh, Y. (1994). Phytoindication of ecological factors. Kyiv: Naukova dumka.

Dilis, N. (1974). Program and methodology of geo-botanical research. Moscow: Nauka.

Domokos, E. \& Domokos J. (2016). Bird communities of different woody vegetation types from the Niraj Valley, Romania. Turk. J. Zool., 40, 734-742. DOI: 10.3906/zoo-1510-64.

Elisa, Maya-Elizarrars \& Schondube J.E. (2015). Birds, charcoal and cattle: Bird community responses to human activities in an oak forest landscape shaped by charcoal extraction. For. Ecol. Manag., 335, 118-128. DOI: 10.1016/j.foreco.2014.09.024.

Erdelen, M. (1984). Bird communities and vegetation structure: I. Correlations and comparisons of simple and diversity indices. Oecologia, 61, 277-284. DOI: 10.1007/BF00396773.

Etterson, M.A., Etterson, J.R. \& Cuthbert F.J. (2007). A robust new method for analyzing community change and an example using 83 years of avian response to forest succession. Biol. Conserv., 138(3-4), 381-389. DOI: 10.1016/j.biocon.2007.05.003.

Eytungen, G. (1949): Forest science. Moscow: Selchozgiz.

Felton, A., Hedwall, P.O., Lindbladh, M., Nyberg, T., Felton, A.M., Holmstrom, E., Wallin, I., Lof, M. \& Brunet J. (2016). The biodiversity contribution of wood plantations: Contrasting the bird communities of Sweden's protected and production oak forests. For. Ecol. Manag., 365(1), 51-60. DOI: 10.1016/j.foreco.2016.01.030.

Fischer, J., Lindenmayer, D.B., Blomberg, S.P., Montague-Drake, R., Felton, A. \& Stein J.A. (2007). Functional richness and relative resilience of bird communities in regions with different land use intensities. Ecosystems, 10(6), 964-974. DOI: 10.1007/s10021-007-9071-6.

Fuller, R.J. \& Moreton B.D. (1987). Breeding bird population of Kentish sweet chestnut (Castanea sativa) coppice in relation to age and structure of the coppice. J. Appl. Ecol., 24(1), 13-27. DOI: 10.2307/2403784.

Gabbe, A.P., Robinson, S.K. \& Brawn J.D. (2002). Tree-species preferences of foraging insectivorous birds: Implications for floodplain forest restoration. Conserv. Biol., 16(2), 462-470. DOI: 10.1046/j.1523-1739.2002.00460.x.

Gardner, T., Barlow, J., Araujo, I., Avila-Pires, T., Bonaldo, A., Costa, J., Esposito, M., Ferreira, L., Hawes, J., Hernandez, M., Hoogmoed, M., Leite, R., Lo-Man-Hung, N., Malcolm, J., Martins, M., Mestre, L., Miranda-Santos, R. Overal, W., Parry, L., Peters, S., Ribeiro-Junior, M., Silva, M. \& Peres C. (2008). The cost-effectiveness of biodiversity surveys in tropical forests. Ecol. Lett., 11(2), 139-150. DOI: 10.1111/j.1461-0248.2007.01133.x.

Gavriluk, V. (1956). Nature of Kyiv City and the surrounding area: physical-geographical characteristics. Kyiv: Publisher Shevchenko University.

Gill, R. (2006). Influence of large herbivores on tree recruitment and forest dynamics. In K. Danell, R. Bergstrom, P. Duncan \& J. Pastor (Eds.), Large herbivore ecology, ecosystem dynamics and conservation. Cambridge: Cambridge Scientific Press.

Graham, C., Wilson, M., Gittings, T., Kelly, T., Irwin, S., Sweeney, O. \& O’Halloran J. (2014). Factors affecting the bird diversity of planted and semi-natural oak forests in Ireland. Bird Study, 61, 309-320. DOI: 10.1080/00063657.2014.927415. 
Grimm, N.B., Faeth, S.H., Golubiewski, N.E., Redman, C.L., Wu, J., Bai, X. \& Briggs J.M. (2008). Global change and the ecology of cities. Science, 319(5864), 756-760. DOI: 10.1126/science.1150195.

Giltena, A., Saura, S. \& Brotons L. (2007). Effects of forest composition and structure on bird species richness in a Mediterranean context: implications for forest ecosystem management. For. Ecol. Manag., 242(3-4), 470-476. DOI: 10.1016/j.foreco.2007.01.080.

Heyman, E. (2010). Clearance of understory in urban woodlands: assessing impact on bird abundance and diversity. For. Ecol. Manag., 260(1), 125-131. DOI: 10.1016/j.foreco.2010.04.011.

Hinsley, S., Bellamy, P., Newton, I. \& Sparks T. (1995). Habitat and landscape factors influencing the presence of individual breeding bird species in woodland fragments. J. Avian Biol., 26, 94-104. DOI: 10.2307/3677057.

Ikin, K., Barton, P.S., Stirnemann, I.A., Stein, J.R., Michael, D., Crane, M., Okada, S. \& Lindenmayer D.B. (2014). Multiscale associations between vegetation cover and woodland bird communities across a large agricultural region. PLOS ONE, 9, e97029.

International Code of Zoological Nomenclature adopted by the International Union of Biological Sciences (Internet) (1999). London: International Trust for Zoological Nomenclature. http://www.nhm.ac.uk/hosted-sites/iczn/code/

James, F. \& Wamer N. (1982). Relationships between temperate forest bird communities and vegetation structure. Ecology, 63, 159-171. DOI: 10.2307/1937041.

Järvinen, O. \& Väisänen R.A. (1975). Estimating relative densities of breeding birds by the line transect method. Oikos, 26(3), 316-322. DOI: 10.2307/3543502.

Katsimanis, N., Dretakis, D., Akriotis, T. \& Mylonas M. (2006). Breeding bird assemblages of eastern Mediterranean shrublands: composition, organisation and patterns of diversity. Journal of Ornithology, 147(3), 419-427. DOI: 10.1007/s10336-005-0024-6.

Klausnitzer, B. (1990). Ecology of urban fauna. Moscow: Mir.

Konishchuk, V., Mosyakin, S., Tsarenko, P., Kondratyuk, S., Borisova, E., Virchenko, V., Prydyuk N., Fitsaylo T., Havrys G., Tytar, V. \& Shupova T. (2012). Red book of the Kyiv area. Agroecological Journal, 3, 46-58.

Kurlavichus, P. (1986). Biotopic distribution of birds in agrarian plantations. Vilnjus: Mokslas.

Lavrov, V.V., Blinkova, O.I., Ivanenko, O.M. \& Polischuk Z.V. (2016a). Consortial relations of aphyllophoroid fungi and Quercus robur L. in places of industrial granite mining and recreational activities. Studia Biologica, 10(2), $163-174$.

Lavrov, V., Blinkova, O., Miroshnik, N. \& Ivanenko O. (2016b). Synecological principles of diagnostics of transformation of structural and functional organization of forest ecosystems in the evolutionary aspect. Factors in Experimental Evolution Organisms, 18, 186-190.

MacArthur, R. \& MacArthur J. (1961). On bird species diversity. Ecology, 42, 594-598. DOI: 10.2307/1932254.

Magurran, E. (1998). Ecological diversity and its measurement. New Jersey: Princeton University Press.

Martin, K. \& Eadie J.M. (1999). Nest webs: a community-wide approach to the management and conservation of cavity-nesting forest birds. For. Ecol. Manag., 115, 243-257. DOI: 10.1016/S0378-1127(98)00403-4.

Martin, J.-L. \& Joron M. (2003). Nest predation in forest birds: influence of predator type and predator's habitat quality. Oikos, 102, 641-653. DOI: 10.1034/j.1600-0706.2003.12040.x.

Marzluff, J.M., Gehlbach, F.R. \& Manuwal D.A. (1998). Urban environments: influences on avifauna and challenges for the avian conservationist. In J.M. Marzluff \& R. Sallabanks (Eds.), Avian conservation: research and management. Washington: Island Press.

Mcneill, J. (2011). International code of nomenclature for algae, fungi and plants (Melbourne Code) adopted by the Eighteenth International Botanical Congress. Melbourne, Australia. Available from: http://www.iapt-taxon.org/ nomen/main.php)

Migunova, E. (1993). Forests and forest land (quantitative assessment of relationships). Moscow: Ecology.

Mikusinski, G., Gromadzki, M. \& Chylarecki P. (2001). Woodpeckers as indicators of forest bird diversity. Conserv. Biol., 15(1), 208-217. DOI: 10.1111/j.1523-1739.2001.99236.x.

Milne, R.J. (2003). The relationships of vegetation and bird communities with landforms and geomorphic processes on the Central Niagara Escarpment (Ontario). Theses and Dissertations (Comprehensive).

Mirkin, V., Naumova, L. \& Solomeshh A. (2002). The modern science of vegetation. Moscow: Logos.

Møller, A.P., Diaz, M., Flensted-Jensen, E., Grim, T., Ibanez-Alamo, J.D., Jokimäki, J., Mand, R., Marko, G. \& Tryjanowski P. (2015). Urbanized birds have superior establishment success in novel environments. Oecologia, 178(3), 943-950. DOI: 10.1007/s00442-015-3268-8.

Moreno-Rueda, G. \& Pizzaro M. (2009). Relative influence of habitat heterogeneity, climate, human disturbance, and spatial structure on vertebrate species richness in Spain. Ecol. Res., 24(2), 335-344. DOI: 10.1007/s11284008-0509-x. 
Mosyakin, S. \& Fedoronchuk M. (1999). Vascular plants of Ukraine a nomenclatural checklist. Kyiv: MG Kholodny Institute Botany.

Muntaner, J., Ferrer, X. \& Martınaez-Vilalta A. (1983). Atles dels ocells nidificants de Catalunya i Andorra. Barcelona: Ketres Editora.

Neshataev, J. (1987). Methods of analysis of geobotanical materials. Leningrad: Leningrad University.

Novikov, G. (1953). Field studies on the ecology of terrestrial vertebrates. Moscow: Soviet Science.

O'Connor, R. (1981). Habitat correlates of bird distribution in British census plots. Studies in Avian Biology, 6, 533-537.

Pereira, P., Godinho, C., Roque, I., Marques, A., Branco, M. \& Rabaca J.E. (2014). Time to rethink the management intensity in a Mediterranean oak woodland: the response of insectivorous birds and leaf-chewing defoliators as key groups in the forest ecosystem. Ann. For. Sci., 71(1), 25-32. DOI: 10.1007/s13595-012-0227-y.

Polyakov, A.P. \& Plugatar Y.V. (2009). Forest formations of Crimea and their ecological role. Kharkiv.

Rabotnov, T.A. (1992). Phytocoenology. Moscow: University Moscow.

Ramenskii, L. (1971). Problems and methods of studying vegetation cover. Leningrad: Nauka.

Roberge, J.M. \& Angelstam P. (2006). Indicator species among resident forest birds - a cross-regional evaluation in northern Europe. Biol. Conserv., 130(1), 134-147. DOI: 10.1016/j.biocon.2005.12.008

Robles, H., Ciudad, C., Vera, R., Olea, P.P., Purroy, F.J. \& Matthysen E. (2007). Sylvopastoral management and conservation of the middle spotted woodpecker at the south-western edge of its distribution range. For. Ecol. Manag., 242, 343-352. DOI: 10.1016/j.foreco.2007.01.052.

Robles, H., Ciudad, C. \& Matthysen E. (2011). Tree-cavity occurrence, cavity occupation and reproductive performance of secondary cavity-nesting birds in oak forests: The role of traditional management practices. For. Ecol. Manag., 261(8), 1428-1435. DOI: 10.1016/j.foreco.2011.01.029.

Robles, H., Ciudad, C. \& Matthysen E. (2012). Responses to experimental reduction and increase of cavities by a secondary cavity-nesting bird community in cavity-rich Pyrenean oak forests. For. Ecol. Manag., 277, 46-53. DOI: 10.1016/j.foreco.2012.04.017.

Rodewald, A. \& Abrams M. (2002). Floristics and avian community structure: implications for regional changes in eastern forest composition. J. For. Sci., 48, 267-272.

Rusin, L. (2003). Monitoring of recreational forests. Moscow: RAN.

Sanitary Forest Regulation in Ukraine (2016). Resolution of government of Ukraine. No. 756. Kyiv.

Sekercioğlu, C. (2002). Effects of forestry practices on vegetation structure and bird community of Kibale National Park, Uganda. Biol. Conserv., 107(2), 229-240. DOI: 10.1016/S0006-3207(02)00097-6.

Sekercioğlu, C. (2006). Increasing awareness of avian ecological function. Trends Ecol. Evol., 21(8), 464-471. DOI: 10.1016/j.tree.2006.05.007.

Shirihai, H., Gargallo, G. \& Helbig A. (2001). Sylvia Warblers. In Ch. Helm (Ed.), Identification, taxonomy and phylogeny of the Genus Sylvia. London: Black.

Snow, D. \& Perrins C. (1998). The birds of the Western Palearctic. Vol. 2: Passerines. Oxford: Oxford University Press.

Shupova, T. (2014). Avifauna in settlement zone of Kiev. J. Karazin Kharkiv National Univ. Ser. Biol., 21(1112), 83-91.

Shupova, T. (2017). The transformation of the diversity of avifauna under the influence of recreational load. Biosyst. Divers., 25(1), 45-51. DOI https://doi.org/10.15421/011707.

Šalek, M., Svobodova, J. \& Zasadil P. (2010). Edge effect of low-traffic forest roads on bird communities in secondary production forests in central Europe. Landsc. Ecol., 25(7), 1113-1124. DOI: 10.1007/s10980-010-9487-9.

Tews, J., Brose, U., Grimm, V., Tielborger, K., Wichmann, M.C., Schwager, M. \& Jeltsch F. (2004). Animal species diversity driven by habitat heterogeneity/diversity: the importance of keystone structures. J. Biogeogr., 31(1), 79-92. DOI: 10.1046/j.0305-0270.2003.00994.x.

Tomiałojc, L. (2007). Changes in the avifauna in two parks in Legnica after 40 years. Notatki Ornitologiczne, 4 , $232-245$.

Touihri, M., Villard, M.A. \& Charfi F. (2014). Cavity-nesting birds show threshold responses to stand structure in native oak forests of northwestern Tunisia. For. Ecol. Manag., 325, 1-7. DOI: 10.1016/j.foreco.2014.03.050.

Vasilevich, V. (1992). Biological diversity: approaches to the study and conservation. Saint Petersburg: ZinRan.

Virkkala, R. (2006). Why study woodpeckers? The significance of woodpeckers in forest ecosystems. Ann. Zool. Fenn., 43(2), 82-85. http://www.sekj.org/AnnZool.html.

Walther, B. (2002). Vertical stratification and use of vegetation and light habitats by Neotropical forest birds. Journal of Ornithology, 143, 64-81. DOI: 10.1007/BF02465460. 
Wen, W., Maruyama, N., Bo-Wen, L., Morimoto, H. \& Zhong-Xin G. (2002). Relationships between bird communities and vegetation structure in Honghuaerji, northern inner Mongolia. J. For. Res., 13(4), 294-298. DOI: 10.1007/BF02860095.

Whelan, C., Wenny, D. \& Marquis R. (2008). Ecosystem services provided by birds. Ann. N. Y. Acad. Sci., 1134(1), 25-60. DOI: 10.1196/annals.1439.003

White, J.G., Fitzsimons, J.A., Palmer, G.C. \& Antos M.J. (2009). Surviving urbanisation: maintaining bird species diversity in urban Melbourne. Vic. Nat., 126(3), 73-78.

Wilson, M.F. (1974). Avian community organization and habitat structure. Ecology, 55, 1017-1029. DOI: $10.2307 / 1940352$.

Wilson, M., de Santo, T. \& Sabag C. (1994). Avian community of fragmented south-temperate rainforests in Chile. Conserv. Biol., 8, 508-520. DOI: 10.1046/j.1523-1739.1994.08020508.x.

Woodley, S.J., Jonson, G., Freedmanm, B. \& Kirk D.A. (2006). Effects of timber harvesting and plantation development on cavity-nesting birds in New Brunswick. Can. Field-Nat., 120, 298-306.

Zavjalov, E., Shljahtin, G., Tabachishin, V. \& Jakushev N. (2005). Ecological-faunistic characteristic by avifauna of the north of Lower Volga region. J. Saratov Univ. Ser. Chem. Biol. Ecol., 2, 49-59. 
Appendix 1. Conservation status of birds in the experimental plots.

\begin{tabular}{|c|c|c|c|c|c|}
\hline Species & EP1 & EP2 & EP3 & EP4 & Protection category \\
\hline Falco tinnunculus & 0 & 0 & 0 & 1 & Bk2; Bo2; W 2; K \\
\hline Columba palumbus & 0 & 1.3 & 1.1 & 4 & - \\
\hline Columba livia & 0 & 0 & 0 & 7 & Bk3 \\
\hline Cuculus canorus & 0.9 & 0.6 & 0 & 0 & Bk3 \\
\hline Caprimulgus europaeus & 1.8 & 0 & 1.1 & 0 & $\mathrm{Bk} 2$ \\
\hline Jynx torquilla & 0 & 0.6 & 0 & 1 & Bk2 \\
\hline Dryocopus martius & 1.8 & 0 & 1.1 & 0 & $\mathrm{Bk} 2 ; \mathrm{K}$ \\
\hline Dendrocopos major & 1.8 & 1.3 & 2.2 & 5 & $\mathrm{Bk} 2$ \\
\hline Dendrocopos medius & 3.6 & 1.9 & 0 & 2 & $\mathrm{Bk} 2$ \\
\hline Dendrocopos minor & 2.7 & 0.6 & 1.1 & 0 & $\mathrm{Bk} 2$ \\
\hline Anthus trivialis & 0.9 & 0.6 & 3.3 & 0 & $\mathrm{Bk} 2$ \\
\hline Lanius collurio & 0 & 0 & 3.3 & 0 & Bk2 \\
\hline Lanius minor & 0 & 0.6 & 0 & 0 & $\mathrm{Bk} 2$ \\
\hline Oriolus oriolus & 3.6 & 1.9 & 4.4 & 4 & $\mathrm{Bk} 2$ \\
\hline Sturnus vulgaris & 0.9 & 4.4 & 0 & 18 & - \\
\hline Garrulus glandarius & 0 & 0 & 1.1 & 1 & - \\
\hline Pica pica & 0 & 0 & 0 & 3 & - \\
\hline Corvus cornix & 2.7 & 1.3 & 1.1 & 4 & - \\
\hline Corvus corax & 0 & 0.6 & 0 & 0 & Bk3 \\
\hline Troglodytes troglodytes & 0.9 & 0.6 & 5.5 & 3 & $\mathrm{Bk} 2$ \\
\hline Hippolais icterina & 0.9 & 1.9 & 0 & 0 & Bk2 \\
\hline Sylvia atricapilla & 0.9 & 1.3 & 2.2 & 0 & $\mathrm{Bk} 2$ \\
\hline Sylvia borin & 0 & 0 & 0 & 1 & $\mathrm{Bk} 2$ \\
\hline Phylloscopus collybita & 6.4 & 1.9 & 4.4 & 2 & Bk2 \\
\hline Phylloscopus sibilatrix & 0.9 & 1.3 & 2.2 & 2 & Bk2 \\
\hline Ficedula hypoleuca & 1.8 & 0.6 & 1.1 & 0 & Bk2; Bo2 \\
\hline Ficedula albicollis & 1.8 & 1.9 & 1.1 & 2 & $\mathrm{Bk} 2 ; \mathrm{Bo} 2$ \\
\hline Ficedula parva & 0.9 & 0 & 0 & 0 & $\mathrm{Bk} 2 ; \mathrm{Bo} 2$ \\
\hline Muscicapa striata & 1.8 & 1.9 & 3.3 & 2 & $\mathrm{Bk} 2 ; \mathrm{Bo} 2$ \\
\hline Phoenicurus ochruros & 0 & 0 & 0 & 2 & $\mathrm{Bk} 2 ; \mathrm{Bo} 2$ \\
\hline Erithacus rubecula & 5.5 & 5.6 & 11.1 & 6 & $\mathrm{Bk} 2 ; \mathrm{Bo} 2$ \\
\hline Luscinia luscinia & 5.5 & 3.8 & 3.3 & 3 & $\mathrm{Bk} 2 ; \mathrm{Bo} 2$ \\
\hline Turdus pilaris & 0 & 3.2 & 4.4 & 17 & $\mathrm{Bk} 3 ; \mathrm{Bo} 2$ \\
\hline Turdus merula & 14.5 & 6.3 & 15.5 & 10 & $\mathrm{Bk} 3 ; \mathrm{Bo} 2$ \\
\hline Turdus philomelos & 3.6 & 1.9 & 3.3 & 2 & $\mathrm{Bk} 3 ; \mathrm{Bo} 2$ \\
\hline Aegithalos caudatus & 1.8 & 0.6 & 0 & 0 & $\mathrm{Bk} 2$ \\
\hline Parus palustris & 1.8 & 0 & 2.2 & 0 & $\mathrm{Bk} 2$ \\
\hline Parus ater & 1.8 & 1.3 & 0 & 1 & $\mathrm{Bk} 2$ \\
\hline Parus caeruleus & 2.7 & 1.3 & 0 & 2 & $\mathrm{Bk} 2$ \\
\hline Parus major & 30.9 & 16.3 & 25.5 & 14 & $\mathrm{Bk} 2$ \\
\hline Sitta europaea & 10.9 & 2.5 & 8.9 & 2 & Bk2 \\
\hline Certhia familiaris & 2.7 & 1.3 & 1.1 & 1 & $\mathrm{Bk} 2$ \\
\hline Passer montanus & 3.6 & 0 & $\begin{array}{c}1.1 \\
0\end{array}$ & 6 & Bk3 \\
\hline Fringilla coelebs & 25.5 & 14.4 & 20 & 11 & Bk3 \\
\hline Chloris chloris & 0.9 & 0.6 & 0 & 3 & $\mathrm{Bk} 2$ \\
\hline Carduelis carduelis & 1.8 & 0.6 & 0 & 0 & $\mathrm{Bk} 2$ \\
\hline Acanthis cannabina & 0 & 0 & 0 & 3 & $\mathrm{Bk} 2$ \\
\hline Coccothraustes coccothraustes & 0.9 & 4.4 & 4.4 & 2 & $\mathrm{Bk} 2$ \\
\hline Emberiza citrinella & 0 & 0.6 & 0 & 0 & $\mathrm{Bk} 2$ \\
\hline
\end{tabular}

Bk2, Bk3, categories of The Bern Convention; Bo2, categories of The Bonn Convention; W2, categories of Convention on International Trade in Endangered Species of Wild Fauna and Flora; K, threatened species for Kyiv region (Konishchuk et al., 2012). 